\title{
Interplay of irreversible reactions and deformation: a case of hydrofracturing in the rodingite-serpentinite system
}

\author{
Tadao Nishiyama ${ }^{1 *}$, Chisato Yoshida- Shiosaki, Yasushi Mori and Miki Shigeno ${ }^{2}$
}

\begin{abstract}
The interplay of irreversible reactions and deformation during regional metamorphism was analyzed in the reaction zones between rodingite and serpentinite. Rodingites are leucocratic rocks found commonly in serpentinites and are considered metasomatic products of Ca-rich fluid. Rodingites occur ubiquitously in serpentinite from the Nomo metamorphic rocks, western Kyushu, a Cretaceous accretionary complex of greenschist to epidote-amphibolite facies condition. We used the singular value decomposition (SVD) method to analyze rodingitization reactions based on mineral compositions of a rodingite sample and a possible protolith (clinopyroxene gabbro). The resultant reaction implied that the rodingite was formed due to the addition of considerable amounts of $\mathrm{CaO}$ and $\mathrm{H}_{2} \mathrm{O}$ to the protolith, whereas other components such as $\mathrm{SiO}_{2}, \mathrm{AF}\left(\mathrm{Al}_{2} \mathrm{O}_{3}+\mathrm{Fe}_{2} \mathrm{O}_{3}\right)$, and $\mathrm{FM}(\mathrm{FeO}+\mathrm{MgO})$ were conserved. The Nomo rodingites are associated with reaction zones between serpentinite. A careful study on the compositional variations of diopside and chlorite in the rodingite, serpentinite, and the reaction zones between them showed a disequilibrium crystallization of diopside in the reaction zone. Diopside shows a serrated variation in composition across the reaction zone together with disequilibrium signature within grains (composite grain consisting of Fe-rich and Fe-poor parts). These features clearly indicate that diopside crystallized in a relatively short period compared to the metamorphism by irreversible reactions. Another conspicuous feature is that perovskite occurs in some reaction zones, whereas titanite is common in rodingites; this indicates that the reaction zone is poorer in $\mathrm{SiO}_{2}$. The tremolite veins are typically derived from the reaction zone into serpentinite; showing this is a good example of hydrofracturing associated with the formation of the reaction zone. All the reactions obtained by the SVD method that contribute to the formation of the reaction zones consumed $\mathrm{CaO}$ and evolved $\mathrm{H}_{2} \mathrm{O}$, strongly suggesting that the hydrofracturing is caused by a rapid increment of fluid pressure during the progression of the reactions. The reactions consumed considerable amounts of $\mathrm{SiO}_{2}$ in the reaction zone, which is consistent with the occurrence of perovskite, and the conservation of AF and FM components.
\end{abstract}

Keywords: Rodingite, Singular value decomposition method, Hydrofracturing, Perovskite, Reaction zone, Serpentinite, Irreversible reactions

\section{Introduction}

Metamorphism is a significant crustal process that results in the reconstruction of crustal rocks through various chemical reactions and deformation. Although chemical reactions and deformation in metamorphism have been studied separately in most existing research; however, their interplay has an important role in metamorphism. This

\footnotetext{
* Correspondence: tadao@sci.kumamoto-u.ac.jp

${ }^{1}$ Department of Earth and Environmental Science, Graduate School of Science and Technology, Kumamoto University, 2-39-1, Kurokami, Chuo-ku, Kumamoto 860-8555, Japan

Full list of author information is available at the end of the article
}

study examines hydrofracturing caused by reactions between rodingite and serpentinite during regional metamorphism. The same type of interaction between irreversible reactions and hydrofracturing has been analyzed in a metabasite-marble system from a contact metamorphic aureole in the Hirao Limestone in Kitakyushu, Japan (Nishiyama 1989a). Hydrofracturing is driven by rapid increments of fluid pressure and is therefore likely to occur in contact metamorphic aureoles owing to rapid and irreversible reactions. This paper aims to show the same type of hydrofracturing can occur even in a regional metamorphic terrane, provided the reactions occur irreversibly 
under the constant solid volume conditions. For this purpose, the reaction zones between rodingite and serpentinite in the Nomo metamorphic rocks, western Kyushu, Japan, were used as a case study.

Rodingites are common leucocratic rocks found in serpentinites and are considered metasomatic products of Ca-rich fluid. Rodingites are not petrologically significant because their typical mineral assemblage of diopside + grossular provides little information about their formation conditions, such as pressure and temperature. However, rodingites have attracted attention of petrologists because of their role in fluid-rock interaction in oceanic lithospheres (Austrheim and Prestvik 2008; Frost et al. 2008; Bach and Klein 2009) and subduction zone settings (Koutsovitis et al. 2013; Li et al. 2014). Rodingitization commonly occurs in Ca-rich and Si-deficient environments, although each rodingite has a unique formation setting. The chemical interactions between rodingites and serpentinites and the timing of rodingitization with serpentinization are also important aspects to be considered in the interpretation of the tectonic history of rodingite-bearing ophiolites, especially in subduction zone settings. Studies of rodingites have the potential to provide new information on these issues. In an example of mass transfer analysis associated with rodingitization, Barriga and Fyfe (1983) compared the bulk compositions of rodingites and protolith gabbros from East Liguria, Italy and reported significant enrichment in $\mathrm{CaO}$ and $\mathrm{H}_{2} \mathrm{O}$ in rodingites with remarkable depletion in $\mathrm{SiO}_{2}, \mathrm{Na}_{2} \mathrm{O}, \mathrm{K}_{2} \mathrm{O}$, and $\mathrm{TiO}_{2}$. They suggested that these results were caused by interactions of the rocks with highly alkaline $\mathrm{Ca}-\mathrm{Mg}(\mathrm{OH})_{2}$-rich solutions derived from serpentinites. The isocon method (Grant 2005) is a powerful tool for clarifying the extent of mass transfer due to metasomatism because it compares the bulk compositions. This isocon method utilizes a plot of protolith composition versus altered rock composition and defines the isocon, which is a line connecting the origin of the plot and coordinates of inert components. Because the isocon is occasionally difficult to define in the isocon plot, this method is not universally applicable. The analysis of reaction relations among minerals by the singular value decomposition (SVD) method is an alternative way by means of determining the mass transfer due to metasomatism (Fisher 1989; Lang et al. 2004; Shigeno et al. 2012; Yuguchi et al. 2015). The SVD method is a type of least square method that systematically surveys reaction relations among minerals. Further, the SVD method can show which components are inert components because linear dependence among minerals for a set of components implies the conservation of those components through the reaction produced by the linear dependence. Shigeno et al. (2012) applied both the isocon and SVD methods to jadeitite reaction zones in the Nagasaki Metamorphic Rocks and determined that both the methods produce consistent results.
The purposes of this paper are as follows: First, we discuss rodingitization reaction by comparing the mineral assemblages and chemistries of the protolith gabbro with those of the rodingite. Second, we describe the extent of equilibrium in reaction zones between rodingite and serpentinite to emphasize the significance of irreversible reactions in the formation of reaction zones. Finally, we attempt to clarify the interplay of irreversible reactions and resulting hydrofracturing by using the SVD analysis of the reaction relations.

\section{Methods/Experimental Geological setting}

The Nomo metamorphic rocks (Miyazaki and Nishiyama 1989), located in western Kyushu, Japan (Fig. 1), are ideal for studying rodingite-serpentinite reactions as excellent exposures of serpentinites are present along the coast. The Nomo metamorphic rocks are a member of the Nagasaki Metamorphic Rocks, which are distributed in three discrete regions: the Nishisonogi Peninsula (Nishisonogi metamorphic rocks), Nomo Peninsula (Nomo metamorphic rocks), and Amakusa-Takahama region (Amakusa-Takahama metamorphic rocks). The Nishisonogi and Amakusa-Takahama metamorphic rocks represent ancient subduction complexes of the Cretaceous Period (e.g., Hattori and Isomi 1976; Nishiyama 1989b; Miyazaki et al. 2013). The Nomo metamorphic rocks consist of three geological units of different ages that are in fault contact with one another: 590-460 Ma metagabbro (the older metagabbro; Igi et al. 1979), 250-180 Ma crystalline schists of the Suo unit (Nishimura 1998), and 90-70 Ma crystalline schists and serpentinites of the Sanwa Formation (Hattori and Shibata 1982; Miyazaki and Nishiyama 1989). The studied serpentinite belongs to the Sanwa Formation, in which the crystalline schists overlie the serpentinite body by low-angle thrusts. Some parts of serpentinite have been strongly sheared to form a serpentinite mélange consisting of a matrix (composed of sheared serpentinite or actinolite schist) with tectonic blocks of various types of rocks such as albitites, metagabbros, amphibolites, and meta-volcanics. The crystalline schists show greenschist to epidote-amphibolite facies without high-pressure metamorphism signatures, whereas metabasites (metagabbros and metadorelites) in the serpentinites contain omphacite and alkali amphiboles (magnesio-riebeckite) indicating high $P / T$ metamorphism (Nishiyama and Miyazaki 1987; Miyazaki and Nishiyama 1989). The metabasites occur as metamorphosed dykes and tectonic blocks, both of which are accompanied by reaction zones consisting of chlorite, tremolite, and diopside or omphacite (Nishiyama and Miyazaki 1987). The rodingites occur ubiquitously in the serpentinite. Fukuyama et al. (2014) conducted geochemical and geochronological studies on these rodingites and determined that the $\mathrm{U}-\mathrm{Pb}$ age of the zircons from the rodingites was 108-105 $\mathrm{Ma}$, indicating that the formation 


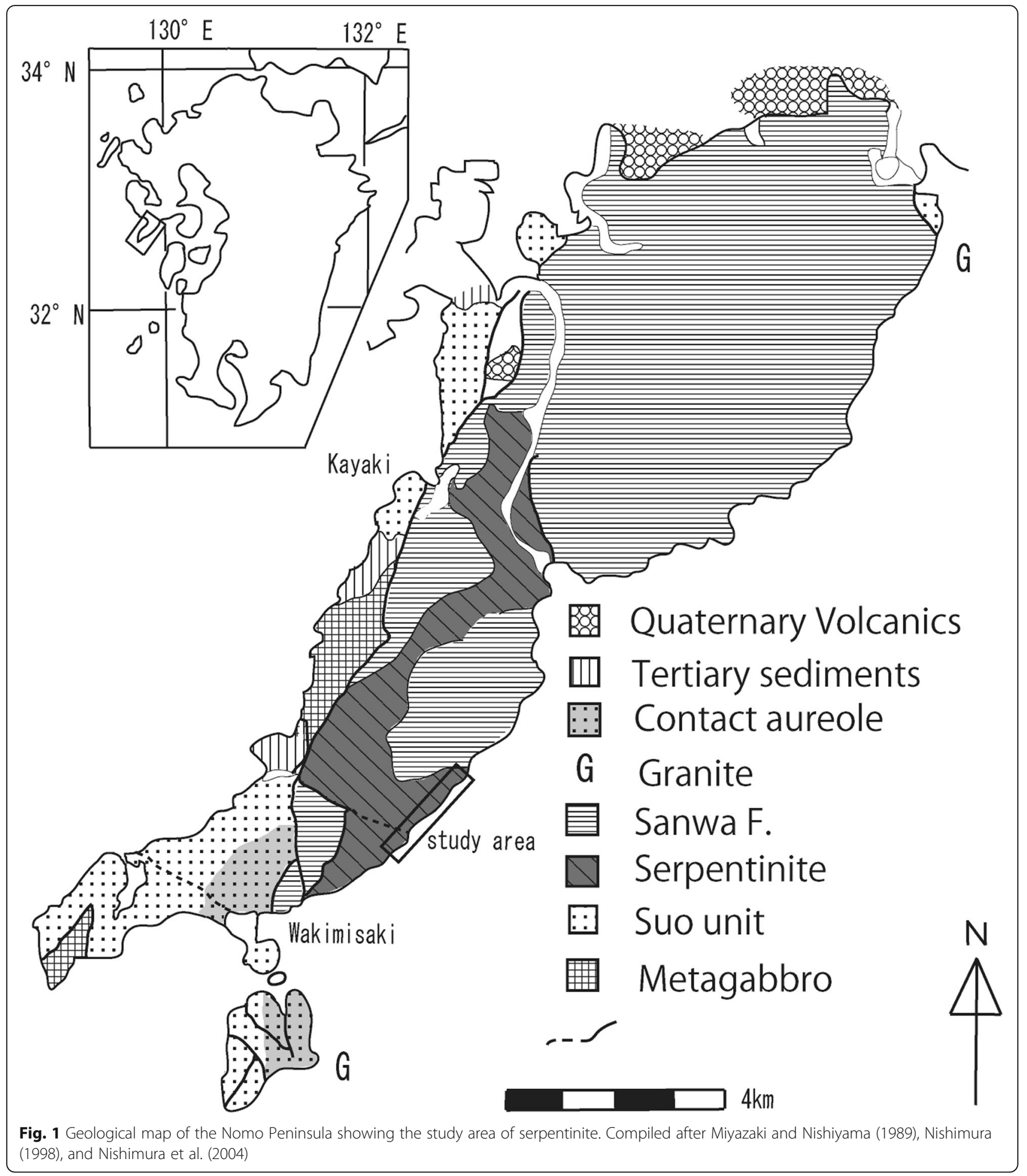

of the rodingites predates the peak metamorphism of the Sanwa Formation. The rodingites mostly occur as metamorphosed dykes, typically 20 to $50 \mathrm{~cm}$ thick in the serpentinite, and occasionally as tectonic blocks with chlorite-rich reaction zones in a serpentinite mélange. Some rodingites occur in the serpentinite as thin veins of several centimeters in width, with a meandering structure. The rodingites show a gabbroic texture in some cases; however, a transition from metagabbro (diopside + clinozoisite) to rodingite (grossular + diopside) was not observed in outcrops from the study area. Clinopyroxene metagabbros rarely occur as dykes, of several meters in thickness, in the 
serpentinite and are accompanied by reaction zones consisting mainly of chlorite, tremolite, and diopside.

\section{Petrography}

This section describes the petrography and mineral chemistry of representative samples of rodingites, serpentinites, and the reaction zones between them. A possible equivalent to the rodingite protolith (gabbro), a clinopyroxene metagabbro, is also described for comparison. Rodingites are categorized into two types: dyke-type and vein-type. Dyke-type rodingites (Fig. 2a) occur as platy dykes of constant width ranging from 20 to $100 \mathrm{~cm}$ that commonly show coarse-grained gabbroic textures (Fig. 2b). Vein-type rodingites (Fig. 2c) occur as winding or meandering veins of variable width ranging from 1 to $10 \mathrm{~cm}$, sometimes showing branching and no distinct internal textures. Both types of rodingites are associated with the reaction zone between the host serpentinite. Table 1 shows mineral assemblages of rodingites, serpentinites, associated reaction zones, and a clinopyroxene metagabbro. Serpentinites are massive rocks with metamorphosed clinopyroxenite layers of several tens of centimeters in thickness. They consist mainly of serpentine (antigorite) with small amounts of diopside and chlorite. Chromite surrounded by magnetite
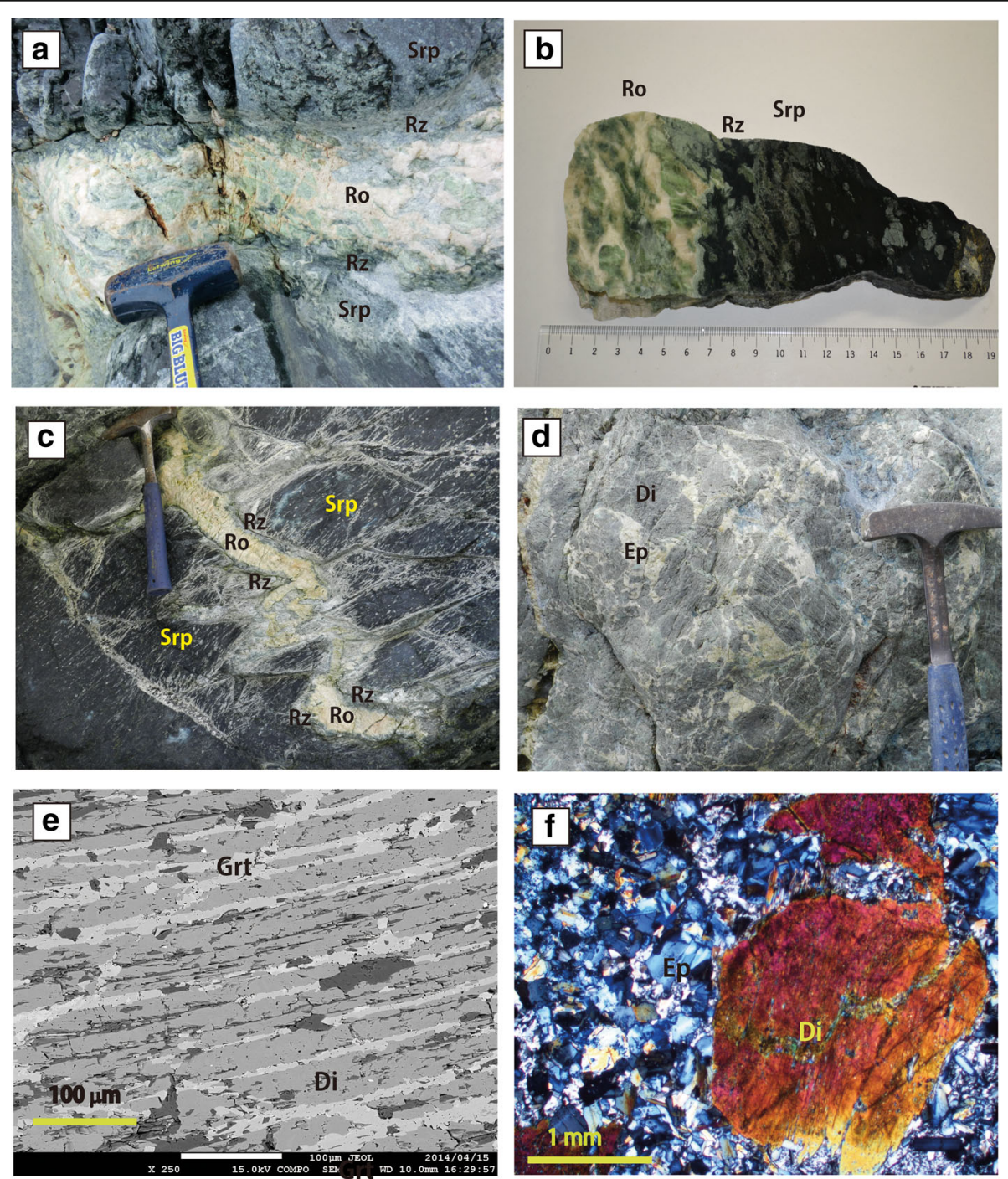

Fig. 2 Photographs of rodingite and metagabbro, back-scattered electron (BSE) image of rodingite, and photomicrograph of metagabbro. a Dyke-type rodingite (Ro, 131018-B) in serpentinite (Sp), consisting of green diopside and white aggregates of garnet and chlorite. The reaction zones (Rz) are developed between them. b Gabbroic texture of the dyke-type rodingite (131018-B), showing large crystals of green diopside embedded in white garnet. c Vein-type rodingite (Ro) in serpentinite (Sp), showing meandering structure, and the reaction zones (RZ) between them. $\mathbf{d}$ Clinopyroxene metagabbro consisting of large crystals of brown diopside and fine-grained aggregates of epidote, chlorite, and titanite. e BSE image of diopside from the rodingite, showing metasomatic development of lamellae-like garnet along the cleavage of diopside. $\mathbf{f}$ Photomicrograph of the clinopyroxene metagabbro under crossed polars 
Table 1 Mineral assemblages of rodingites, serpentinites, associated reaction zones, and a metagabbro

\begin{tabular}{|c|c|c|c|c|c|c|c|c|c|c|c|c|c|c|c|c|c|}
\hline \multirow{2}{*}{$\begin{array}{l}\text { Sample } \\
\text { number }\end{array}$} & \multirow[t]{2}{*}{ Rock type } & \multicolumn{16}{|c|}{ Minerals } \\
\hline & & $\mathrm{Di}$ & Grt & Chl & Srp & Chr & Ep & Ves & Pmp & Amp & Prv & Ttn & $\| \mathrm{m}$ & Mag & Ap & Cal & Zrn \\
\hline 131018-2A & Rodingite $(v)^{a}$ & $\circ$ & $\circ$ & $\circ$ & & & & $\circ$ & & & & o & & & & & \\
\hline 131018-2B & Rodingite(v) & $\circ$ & $\circ$ & $\circ$ & & & & & & & & $\circ$ & & & & & \\
\hline \multirow[t]{2}{*}{$131018-4 A$} & Rodingite(v) & $\circ$ & $\circ$ & $\circ$ & & & & & & & & $\circ$ & $\circ$ & & $\circ$ & & \\
\hline & Reaction zone & $\circ$ & & $\circ$ & & & & & & & $\circ$ & & & & $\circ$ & & \\
\hline \multirow[t]{2}{*}{ 131018-4B } & Rodingite(v) & ० & $\circ$ & $\circ$ & & & & & & & & $\circ$ & & & $\circ$ & & \\
\hline & Reaction zone & ० & $\circ$ & $\circ$ & & & & $\circ$ & & & $\circ$ & ० & $\circ$ & & & & \\
\hline \multirow[t]{3}{*}{$131019-2$} & Rodingite(d) & $\circ$ & $\circ$ & $\circ$ & & & & ○ & & & & & & & & & \\
\hline & Reaction zone & ० & & $\circ$ & & & & $\circ$ & & & $\circ$ & & & & & & \\
\hline & Serpentinite & $\circ$ & & $\circ$ & $\circ$ & & & & & & & & & $\circ$ & & & \\
\hline \multirow[t]{3}{*}{ TNKoba } & Rodingite(v) & $\circ$ & $\circ$ & & & & & $\circ$ & & & & & & & & & \\
\hline & Reaction zone & $\circ$ & $\circ$ & $\circ$ & & & & & & & $\circ$ & & & & & & \\
\hline & Serpentinite & $\circ$ & & & ० & $\circ$ & & & & & & & & $\circ$ & & & \\
\hline \multirow[t]{2}{*}{ 08315-0 } & Rodingite(v) & ० & $\circ$ & $\circ$ & & & & & & & & $\circ$ & & & & $\circ$ & $\circ$ \\
\hline & Reaction zone & & & $\circ$ & & & & & & & & $\circ$ & & $\circ$ & $\circ$ & & $\circ$ \\
\hline 131018-1B & Rodingite $(d)^{b}$ & $\circ$ & $\circ$ & $\circ$ & & & & & & & & & & & & $\circ$ & \\
\hline 131019-1core & Rodingite(d) & $\circ$ & $\circ$ & $\circ$ & & & $\circ$ & & $\circ$ & ○ & & $\circ$ & & & $\circ$ & & $\circ$ \\
\hline \multirow[t]{3}{*}{ 131019-1 rim } & Rodingite(d) & ० & $\circ$ & $\circ$ & & & & ○ & & & & $\circ$ & $\circ$ & & $\circ$ & & \\
\hline & Reaction zone & $\circ$ & & $\circ$ & & & & & & & & $\circ$ & $\circ$ & $\circ$ & & & \\
\hline & Serpentinite & $\circ$ & & & $\circ$ & & & & & & & & & $\circ$ & & & \\
\hline 131019MG & Metagabbro & $\circ$ & & $\circ$ & & & $\circ$ & & & & & $\circ$ & & & & $\circ$ & \\
\hline
\end{tabular}

${ }^{\text {a }}$ Rodingite(v) : vein-type rodingite

${ }^{\mathrm{b}}$ Rodingite (d) : dyke-type rodingite. Mineral abbreviations after Whitney and Evans (2010)

occasionally occurs as an accessory mineral. Tremolite and diopside commonly occur as monomineralic veins in serpentinites. Chlorite and diopside are the main constituents in the reaction zones between the rodingites and serpentinites. Small amounts of garnet and vesuvianite occasionally occur close to the rodingites. Titanite (CaTi$\left.\mathrm{SiO}_{5}\right)$, ilmenite, magnetite, apatite, and zircon occur as accessory minerals. Notably, perovskite $\left(\mathrm{CaTiO}_{3}\right)$ was found to occur in several samples of reaction zones, but not in the rodingites or serpentinites. The significance of perovskite occurrence will be discussed subsequently in detail. The minerals were analyzed with using a JEOL JSM7001F fieldemission electron microscope equipped with an Oxford INCA X-Max energy dispersive X-ray analyzer at an accelerating voltage of $15 \mathrm{kV}$ and a beam current of $1.02 \mathrm{nA}$. Some minerals were identified with using a Horiba Jobin Yvon LabRAM HR800 Raman spectrometer equipped with a $633 \mathrm{He}-\mathrm{Ne}$ laser at Kumamoto University. Mineral abbreviations in tables, figures, and equations follow those given in Whitney and Evans (2010).

\section{Dyke-type rodingite and clinopyroxene metagabbro}

A dyke-type rodingite (131018-1B) with a gabbroic texture and a clinopyroxene metagabbro (131019MG) are described in this subsection, and are subsequently discussed in conjunction with the rodingitization of gabbro. Figure 2 shows photographs and photomicrographs of the samples. The rodingite (Fig. 2a) occurs as a $20 \mathrm{~cm}$-thick dyke, with a $1 \mathrm{~cm}$ wide reaction zone, in serpentinite. It shows a coarsegrained gabbroic texture (Fig. $2 \mathrm{~b}$ ) with prismatic crystals of green diopside and fine-grained aggregate of white garnet. The relative abundance of diopside and garnet is roughly 50:50, although the exact determination of modal abundance is hampered by the fine-grained and turbid texture of the rodingite. Microscopic analysis reveals that the large crystals of diopside are partially replaced by aggregates of fine-grained garnet along the cleavage (Fig. 2e). Table 2 summarizes the average compositions of the minerals. An analysis of 10 grains of diopside showed that they contain small amounts of $\mathrm{Al}_{2} \mathrm{O}_{3}(1.18 \mathrm{wt} \%)$ and have an average $\mathrm{X}_{\mathrm{Mg}}\left(\mathrm{Mg} /\left(\mathrm{Mg}+\mathrm{Fe}^{2+}\right)\right)$ of 0.92 . The garnets are all finegrained, showing a local heterogeneity with $\mathrm{Fe}^{3+}$-rich and $\mathrm{Fe}^{3+}$-poor aggregates, $\mathrm{Sps}_{1} \mathrm{Grs}_{82} \mathrm{Adr}_{17}$ and $\mathrm{Grs}_{96} \mathrm{Adr}_{4}$ in compositions, respectively. The total iron in garnets is assumed to be ferric, making the total cation close to 8.0. The chlorite shows $\mathrm{X}_{\mathrm{Mg}}=0.93$, which is almost identical to that of diopside. The clinopyroxene metagabbro (Fig. 2d) occurs as a dyke in serpentinite, with $\sim 20 \mathrm{~cm}$-thick reaction 
Table 2 Average compositions of minerals from dyke-type rodingite and metagabbro

\begin{tabular}{|c|c|c|c|c|c|c|c|c|}
\hline & & ke-type ro & 31018-1E & & & Metagab & 19-MG & \\
\hline & $\mathrm{Di}$ & $\mathrm{Grt1}^{\mathrm{a}}$ & Grt $2^{b}$ & $\mathrm{Chl}$ & $\mathrm{Di}$ & $\mathrm{Chl}$ & Ttn & $\mathrm{Ep}$ \\
\hline & $n^{c}=10$ & $n=7$ & $n=10$ & $n=6$ & $n=5$ & $n=3$ & $n=3$ & $n=13$ \\
\hline $\mathrm{SiO}_{2}$ & 54.66 & 39.26 & 39.95 & 29.69 & 53.32 & 29.81 & 30.75 & 39.26 \\
\hline $\mathrm{TiO}_{2}$ & - & 0.15 & - & - & - & - & 38.47 & - \\
\hline $\mathrm{Al}_{2} \mathrm{O}_{3}$ & 1.18 & 18.04 & 21.49 & 21.18 & 2.01 & 20.25 & 1.19 & 29.10 \\
\hline $\mathrm{Fe}_{2} \mathrm{O}_{3}$ & - & 5.85 & 1.34 & - & - & - & - & 5.40 \\
\hline $\mathrm{FeO}$ & 2.59 & - & - & 3.77 & 4.93 & 4.55 & 0.41 & - \\
\hline $\mathrm{MnO}$ & - & 0.50 & - & - & - & 0.19 & - & - \\
\hline $\mathrm{MgO}$ & 16.81 & - & - & 29.70 & 15.61 & 29.48 & - & - \\
\hline $\mathrm{CaO}$ & 24.80 & 36.17 & 36.96 & 0.09 & 23.72 & - & 29.10 & 24.68 \\
\hline $\mathrm{Na}_{2} \mathrm{O}$ & - & - & - & - & 0.44 & - & - & - \\
\hline Total & 100.04 & 99.97 & 99.74 & 84.43 & 100.03 & 84.28 & 99.92 & 98.44 \\
\hline & & apfu & & & & apfu & & \\
\hline O & 6 & 12 & 12 & 28 & 6 & 28 & 5 & 12.5 \\
\hline Si & 1.98 & 3.01 & 3.01 & 5.76 & 1.95 & 5.82 & 1.00 & 3.02 \\
\hline $\mathrm{Ti}$ & - & 0.01 & - & - & - & - & 0.95 & - \\
\hline Al & 0.05 & 1.63 & 1.91 & 4.84 & 0.09 & 4.66 & 0.05 & 2.64 \\
\hline $\mathrm{Fe}^{3+}$ & - & 0.34 & 0.08 & - & - & - & - & 0.31 \\
\hline $\mathrm{Fe}^{2+}$ & 0.08 & - & - & 0.61 & 0.15 & 0.74 & 0.01 & - \\
\hline $\mathrm{Mn}$ & - & 0.03 & - & - & - & 0.03 & - & - \\
\hline $\mathrm{Mg}$ & 0.91 & - & - & 8.59 & 0.86 & 8.58 & - & - \\
\hline $\mathrm{Ca}$ & 0.96 & 2.97 & 2.98 & 0.02 & 0.93 & - & 1.02 & 2.03 \\
\hline $\mathrm{Na}$ & - & - & - & - & 0.03 & - & - & - \\
\hline Ecation & 3.98 & 7.99 & 7.98 & 19.82 & 4.01 & 19.83 & 3.03 & 8.00 \\
\hline$X_{M g}$ & 0.92 & - & - & 0.93 & 0.85 & 0.92 & - & - \\
\hline$X_{\text {Sps }}$ & - & 0.01 & - & - & - & - & - & - \\
\hline$X_{\text {Grs }}$ & - & 0.82 & 0.96 & - & - & - & - & - \\
\hline$X_{\text {Adr }}$ & - & 0.17 & 0.04 & - & - & - & - & - \\
\hline
\end{tabular}

${ }^{\mathrm{a}} \mathrm{Grt1}$ : Fe-rich garnet

${ }^{\mathrm{b}} \mathrm{Grt2}$ : Fe-poor garnet

'n: number of analyzed grains

zones between them consisting of chlorite and diopside. The rock is massive and very coarse-grained, consisting of darkbrown clinopyroxene crystals, up to $10 \mathrm{~cm}$ in length, and white finer-grained aggregates of chlorite, epidote, and titanite (Fig. 2f). The mode of the rock was determined as $\mathrm{Di}=$ 65 vol.\%, $\mathrm{Ep}=28$ vol.\%, and $\mathrm{Chl}=7$ vol.\% by the pointcounting method. The diopside contains small amounts of $\mathrm{Al}_{2} \mathrm{O}_{3}$ and $\mathrm{Na}_{2} \mathrm{O}$ (Table 2), with $\mathrm{X}_{\mathrm{Mg}}=0.85$, which is slightly lower than that of the diopside from the rodingite. The chlorite, apart from its low content of $\mathrm{MnO}$, has almost the same composition as that of the chlorite from the rodingite. Ferric iron content in epidote is 0.31 atoms per formula unit (apfu).

\section{Dyke-type rodingite with reaction zones}

A set of samples of dyke-type rodingite, serpentinite, and rocks from the reaction zone between them were collected from an outcrop block. This particular example is described here for subsequent discussion on the degree of attainment of equilibrium during the formation of the reaction zones. The rodingite (131019-2) occurs as a massive leucocratic rock surrounded by thin $(\sim 4 \mathrm{~cm}$ thick) reaction zones and further by serpentinite (Fig. 3a). The rodingite consists mainly of diopside, vesuvianite, and garnet with a small amount of chlorite. Microscopic analysis revealed that the presence of very fine grains gives it with a turbid appearance, preventing the identification of all minerals (Fig. 3b). This feature is prevalent in most of the rodingite samples. Figure $3 \mathrm{c}$ is a back-scattered electron (BSE) image of the rodingite under the FE-SEM, showing coarser-grained diopside and vesuvianite with finer-grained garnet. Table 3 shows the average compositions of minerals in these rocks. The garnet in the rodingite 

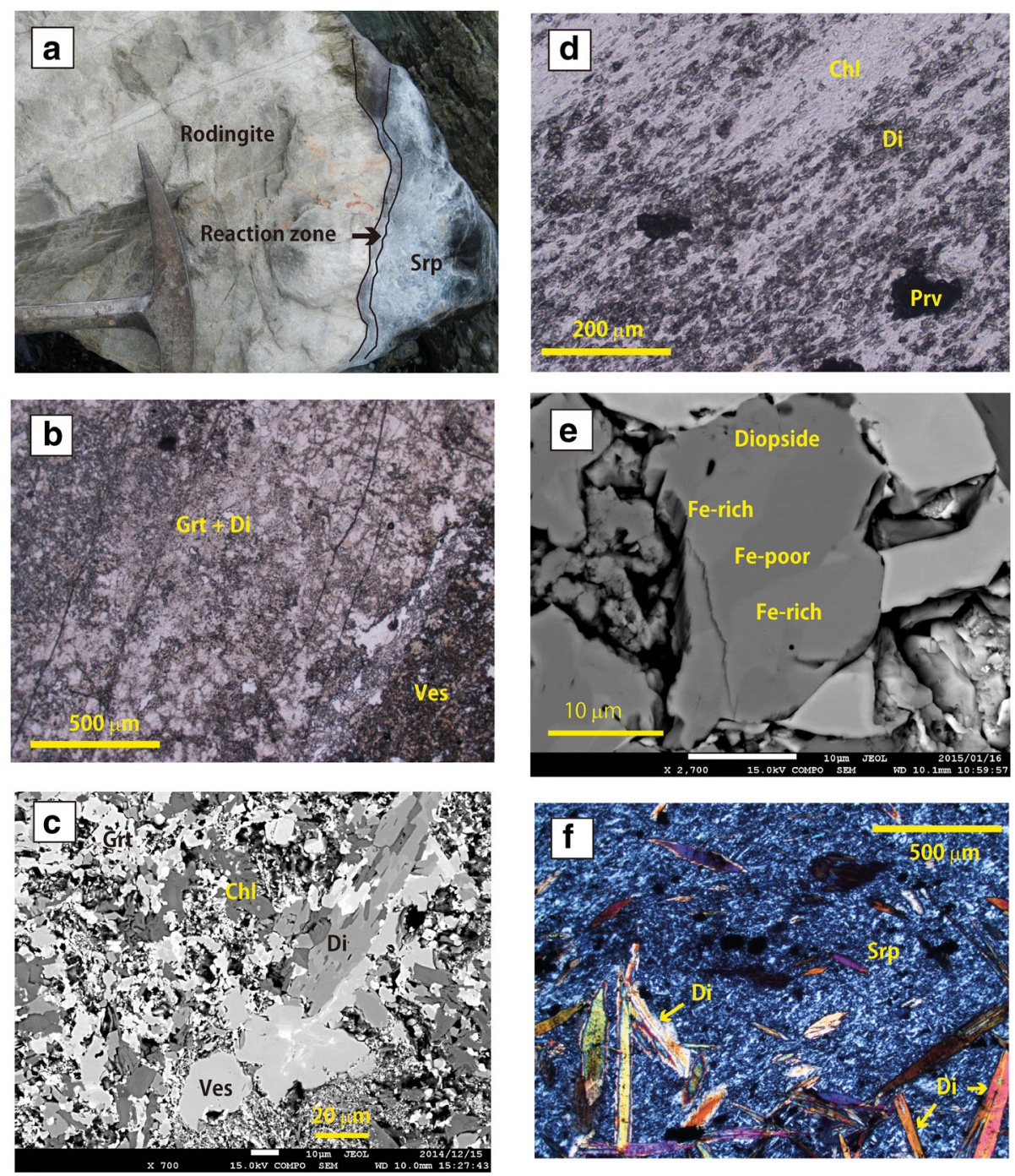

Fig. 3 Photographs, photomicrographs and BSE images of dyke-type rodingite, the reaction zone, and serpentinite. a Photograph of a block of dyke-type rodingite (131019-2) with thin reaction zones between serpentinite (Srp). b Photomicrograph of rodingite (131019-2) consisting of finegrained aggregates of garnet, diopside, and vesuvianite in plane-polarized light. c BSE image of rodingite (131019-2) consisting of garnet, chlorite, diopside, and vesuvianite. $\mathbf{d}$ Photomicrograph of the reaction zone consisting of fine-grained chlorite and diopside with minor perovskite in plane-polarized light. e BSE image of heterogeneous diopside consisting of Fe-rich and Fe-poor parts. $\mathbf{f}$ Photomicrograph of serpentinite consisting of diopside and serpentinite under crossed polars

can be classified into two groups: one rich in $\mathrm{Fe}^{3+}$ (0.68 apfu) and the other poor in $\mathrm{Fe}^{3+}(0.27 \mathrm{apfu})$, considering total iron as $\mathrm{Fe}_{2} \mathrm{O}_{3}$. A small amount of $\mathrm{TiO}_{2}(2-3 \mathrm{wt} \%)$ is present. The Raman spectrum of the garnets poor in $\mathrm{Fe}^{3+}$ represents a broad band at around $3590 \mathrm{~cm}^{-1}$, possibly indicating the presence of $\mathrm{H}_{2} \mathrm{O}$ in the crystal structure. The slightly low total ( 99 wt\%) of the garnet analysis is consistent with this result; thus, the garnet is hydrogrossular. The diopside is magnesian with $\mathrm{X}_{\mathrm{Mg}}=0.96$. The chlorite is richer in $\mathrm{Al}_{2} \mathrm{O}_{3}$ and $\mathrm{FeO}$ than the chlorites from the reaction zones and serpentinite. The systematic compositional change in chlorite composition from rodingite to serpentinite through reaction zones is subsequently discussed. The reaction zones consist of two layers: a dark green, $13 \mathrm{~mm}$-thick layer adjacent to the rodingite (reaction zone 1) and a light green, $6 \mathrm{~mm}$-thick layer adjacent to the serpentinite (reaction zone 2). Reaction zone 1 consists mainly of chlorite with small amounts of diopside, vesuvianite, and perovskite (Fig. 3d), whereas reaction zone 2 is composed mostly of chlorite with a very small amount of diopside. The diopside crystals in the reaction zones are very fine grained (at tens of micrometers in size) and heterogeneous, consisting of Fe-rich and Fe-poor parts (Fig. 3e). The relation between the Fe-rich and Fe-poor parts is 
Table 3 Average compositions of minerals from dyke-type rodingite(131019-2), serpentinite and reaction zones

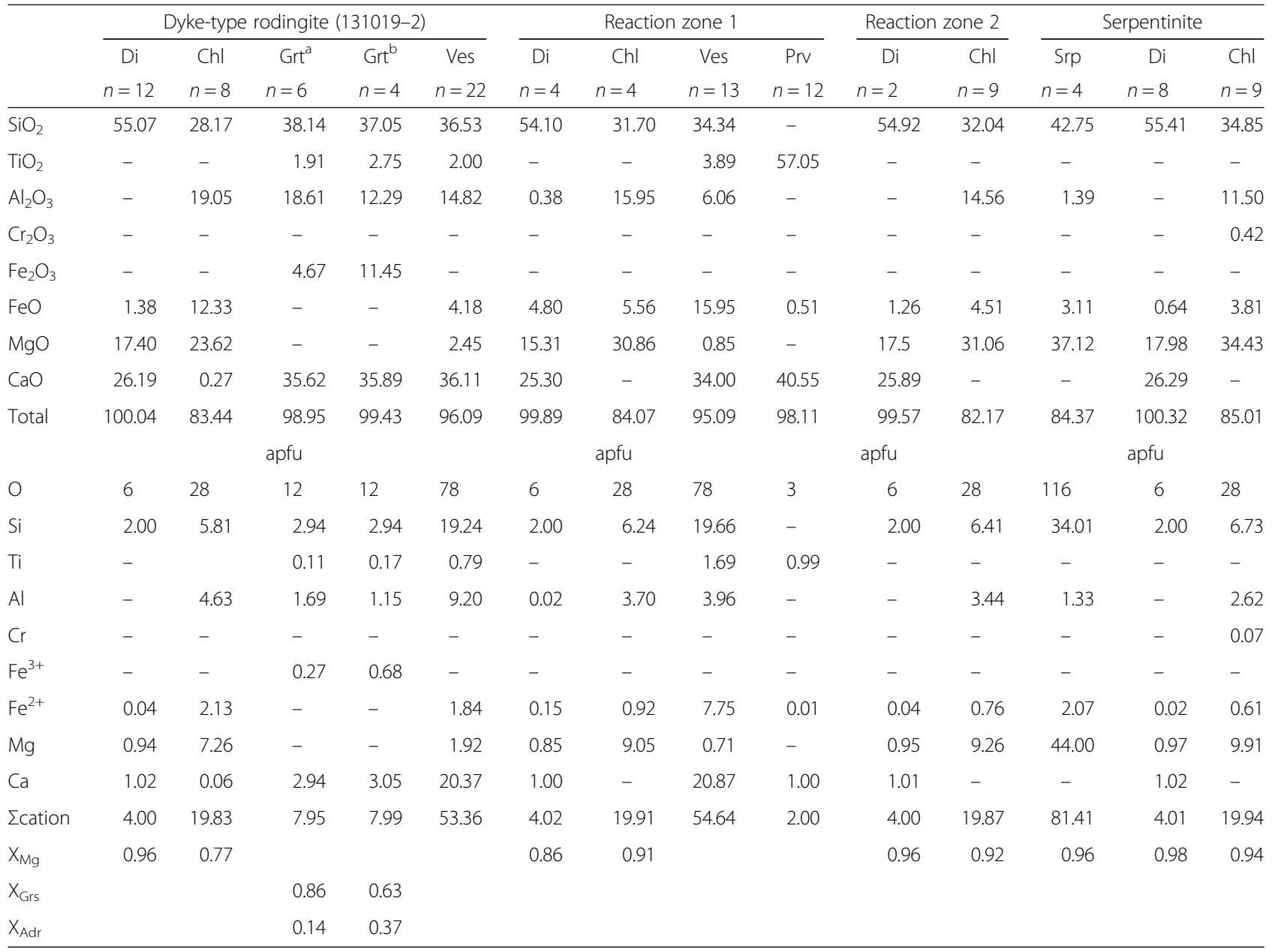

${ }^{\mathrm{a}} \mathrm{Fe} 3+-$ poor garnet

${ }^{\mathrm{b}} \mathrm{Fe} 3+-$ rich garnet

neither a core-rim relationship nor a sector zoning but heterogeneity in individual grains, implying disequilibrium crystallization; this issue is addressed in later discussion subsequently. The serpentinite consists of serpentine (antigorite), diopside, chlorite, and magnetite (Fig. 3f). The diopside shows idiomorphic prismatic crystals with maximum lengths of $500 \mu \mathrm{m}$, which is significantly larger than those in the reaction zones.

\section{Vein-type rodingite with reaction zones}

A vein-type rodingite (131048-4A) associated with reaction zones is described in this subsection in detail and is subsequently discussed in conjunction with the interplay of irreversible reactions and hydrofracturing, which is the main topic of this paper. A conspicuous feature of this particular example is that many tremolite veins are derived from the reaction zones into the serpentinite (Fig. 4a). Similar tremolite veins are commonly observed in wall rock serpentinites that are close to rodingite dykes and veins. Average mineral analyses are given in Table 4 . The rodingite consists mainly of diopside, garnet, and chlorite with small amounts of ilmenite, titanite, and apatite. The garnet is a fine-grained aggregate with a composition of $\mathrm{Grs}_{87} \mathrm{Adr}_{13}$. The diopside occurs as prismatic crystals several hundred micrometers in length within the garnet aggregates. The chlorite occurs in the interstices of the garnet aggregates (Fig. $4 \mathrm{~b}$ ) and has an $\mathrm{X}_{\mathrm{Mg}}$ of 0.70 . The titanite occasionally contains ilmenite in its core (Fig. 4b). The reaction zone is about $1 \mathrm{~cm}$-thick and consists mainly of chlorite and diopside with minor amounts of vesuvianite, perovskite, and apatite. The perovskite shows a symplectic texture with diopside (Fig. 4c), which implies a pseudomorph after titanite. The tremolite veins in the serpentinite are characterized by acicular crystals of tremolite aligned normal to or at high angles to the vein wall (Fig. $4 \mathrm{~d}$ ). The $\mathrm{X}_{\mathrm{Mg}}$ values of ferromagnesian minerals (diopside, chlorite, serpentine, and tremolite) are higher in the serpentinite and the reaction zones than they are in the rodingite (Table 4). 

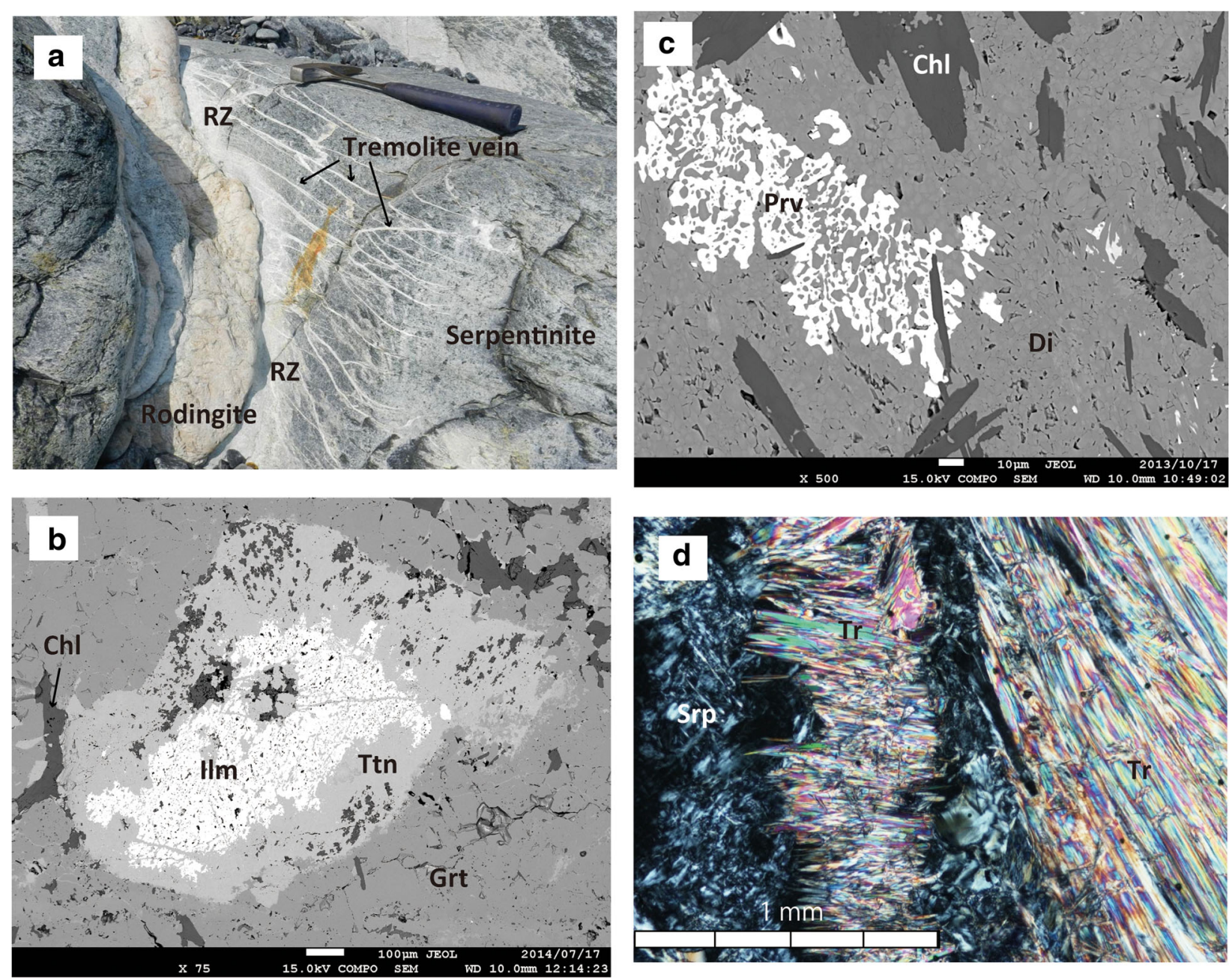

Fig. 4 Photographs, BSE images and photomicrograph of vein-type rodingite, and serpentinite. a Outcrop showing a vein-type rodingite (131018$4 \mathrm{~A})$ and tremolite veins in serpentinite derived from the reaction zone (RZ). $\mathbf{b}$ Titanite crystal containing ilmenite in its core, which was taken from the rodingite (131018-4A). c Perovskite crystal showing a symplectic texture with diopside, likely implying a pseudomorph after titanite. $\mathbf{d}$ Photomicrograph of tremolite veins in serpentinite under crossed polars

\section{Results and Discussion}

Rodingite protolith and rodingite-forming reactions

Rodingite can be formed from various protoliths such as gabbroic rocks (Coleman 1967; O’Brien and Rodgers 1973; Honnorez and Kirst 1975; Leach and Rodgers 1978; Muraoka 1985; Kobayashi and Kaneda 2010), basaltic rocks (Coleman 1967; Evans et al. 1979; Barriga and Fyfe 1983), amphibolite (Karakida 1980), diorite (Hatzipanagioutou and Tsikouras 2001), quartzite (El-Shazly and Al-Belushi 2004), and granite (Wares and Martin 1980). In the study area, gabbro (now metagabbro) is the only possible protolith of rodingite as no other rock types are present as dykes in the serpentinite. The gabbroic texture (Fig. 2b) in the dyke-type rodingite (131018-1B) described above also supports this conclusion. This subsection derives rodingite-forming reactions by the SVD method (Fisher 1989) applied to mineral assemblages of the metagabbro (131019-MG) and of the dyke-type rodingite (131018-1B) and discusses the mass transfer associated with rodingite formation in the study area. The metagabbro may have more or less undergone metasomatism but not as much as the rodingites. Here, we assume the metagabbro retained its original composition of the protolith gabbro. The SVD method is a simple but powerful type of total least square method (Van Huffel and Vanderwalle 1991), and that can systematically survey the reaction relations among minerals. First, we construct a matrix of mineral compositions given in atomic proportions per formula unit in the system $\mathrm{CaO}-$ $\mathrm{SiO}_{2}-\mathrm{AF}\left(\mathrm{Al}_{2} \mathrm{O}_{3}+\mathrm{Fe}_{2} \mathrm{O}_{3}\right)-\mathrm{FM}(\mathrm{FeO}+\mathrm{MgO})$ as shown in Table 5. Combinations of two oxides into a single component such as AF and FM are simplification in the analysis 
Table 4 Average compositions of minerals from vein-type rodingite (131018-4A), serpentinite, and reaction zones

\begin{tabular}{|c|c|c|c|c|c|c|c|c|c|c|c|}
\hline & & Rod & te $(1310$ & & & & Reac & zone & & Serp & \\
\hline & $\mathrm{Di}$ & Grt & $\mathrm{Chl}$ & $\| \mathrm{m}$ & $\overline{T t n}$ & $\mathrm{Chl}$ & $\mathrm{Di}$ & Prv & Ves & Srp & $\mathrm{Tr}$ \\
\hline & $n=4$ & $n=11$ & $n=1$ & $n=4$ & $n=5$ & $n=21$ & $n=3$ & $n=10$ & $n=5$ & $n=9$ & $n=7$ \\
\hline $\mathrm{SiO}_{2}$ & 54.56 & 39.04 & 27.76 & - & 30.48 & 34.15 & 53.30 & 0.06 & 35.97 & 41.19 & 58.20 \\
\hline $\mathrm{TiO}_{2}$ & - & 1.13 & - & 53.28 & 39.12 & - & 1.61 & 57.91 & 4.97 & - & - \\
\hline $\mathrm{Al}_{2} \mathrm{O}_{3}$ & - & 20.19 & 19.83 & - & 1.10 & 16.18 & - & - & 12.00 & 4.79 & - \\
\hline $\mathrm{Fe}_{2} \mathrm{O}_{3}$ & - & 4.96 & - & - & - & - & - & - & - & - & - \\
\hline $\mathrm{FeO}$ & 5.78 & - & 15.87 & 44.68 & - & 3.55 & 1.59 & 0.68 & 5.83 & 2.86 & 2.07 \\
\hline $\mathrm{MnO}$ & - & - & - & 1.62 & - & - & - & - & - & - & - \\
\hline $\mathrm{MgO}$ & 14.50 & - & 21.18 & 0.42 & - & 33.86 & 16.89 & - & 2.12 & 36.19 & 23.34 \\
\hline $\mathrm{CaO}$ & 25.47 & 34.70 & - & 0.05 & 28.89 & - & 26.38 & 40.95 & 35.99 & - & 13.17 \\
\hline Total & 100.31 & 100.02 & 84.64 & 100.05 & 99.59 & 87.74 & 99.77 & 99.60 & 96.88 & 85.03 & 96.78 \\
\hline O & 6 & 12 & 28 & 3 & 5 & 28 & 6 & 3 & 78 & 116 & 23 \\
\hline $\mathrm{Si}$ & 2.01 & 2.96 & 5.74 & - & 1.00 & 6.36 & 1.95 & - & 19.05 & 32.40 & 8.02 \\
\hline $\mathrm{Ti}$ & - & 0.06 & - & 0.76 & 0.96 & - & 0.05 & 0.98 & 1.99 & - & - \\
\hline $\mathrm{Al}$ & - & 1.81 & 4.83 & - & 0.04 & 3.55 & - & - & 7.44 & 4.43 & - \\
\hline $\mathrm{Fe}^{3+}$ & - & 0.28 & - & - & - & - & - & - & - & - & - \\
\hline $\mathrm{Fe}^{2+}$ & 0.18 & - & 2.74 & 0.94 & - & 0.55 & 0.05 & 0.01 & 2.65 & 1.91 & 0.24 \\
\hline $\mathrm{Mn}$ & - & - & - & 0.03 & - & & - & - & - & - & - \\
\hline $\mathrm{Mg}$ & 0.80 & - & 6.53 & 0.02 & - & 9.40 & 0.92 & - & 1.65 & 42.46 & 4.79 \\
\hline $\mathrm{Ca}$ & 1.01 & 2.82 & - & 0.25 & 1.01 & - & 1.04 & 0.99 & 20.45 & - & 1.94 \\
\hline ¿cation & 4.00 & 7.93 & 19.84 & 2.00 & 3.01 & 19.86 & 4.01 & 1.98 & 53.23 & 81.20 & 14.99 \\
\hline$X_{M g}$ & 0.82 & & 0.70 & & & 0.94 & 0.95 & & & 0.96 & 0.95 \\
\hline$X_{\text {Grs }}$ & & 0.87 & & & & & & & & & \\
\hline$X_{\text {Adr }}$ & & 0.13 & & & & & & & & & \\
\hline
\end{tabular}

because combined oxides take part in exchange reactions if treated separately, rather than in net-transfer reactions. The reactants are diopside $(\mathrm{Di})$, chlorite $(\mathrm{Chl})$, and epidote $(\mathrm{Ep})$ in the metagabbro, and diopside $\left(\mathrm{Di}^{\mathrm{R}}\right)$, garnet $\left(\mathrm{Grt}^{\mathrm{R}}\right)$, and chlorite $\left(\mathrm{Chl}^{\mathrm{R}}\right)$ in the rodingite. The superscript $\mathrm{R}$ in abbreviated names denotes minerals in rodingite. The SVD analysis gives linear dependence among these minerals, corresponding to the stoichiometry in reaction relations. Among them, only those satisfying proper sign convention (negative for reactants and positive for products) are judged as proper reactions. We first tried to determine the reaction relations from the four-component system but were unable to get proper reaction relations. We then tried the three-component subsystems, in which the arbitrary component is subtracted. Table 5 shows the three reactions, reactions 1 to 3 , in the $\mathrm{SiO}_{2}-\mathrm{AF}-\mathrm{FM}$ subsystem. All these reactions, however, cannot be considered as proper reactions because reactions 1 and 2 do not satisfy the sign convention, and reaction 3 produces low quantities of garnet. We then examined linear combinations of these reactions, which can also give reaction relations among these minerals. As a result, four reactions in Table 5, $\left[\mathrm{Di}^{\mathrm{R}}\right] 2 \& 3,\left[\mathrm{Grt}^{\mathrm{R}}\right] 2 \& 3,[\mathrm{Di}] 3 \& 1$, and $[\mathrm{Grt}] 3 \& 1$, were obtained as proper reactions, where the mineral name in parentheses stands for mineral phase absent from the reaction, and $2 \& 3$ following the parenthesis denotes linear combination of the reactions, e.g., reactions 2 and 3 and so on. Among the four reactions, only $\left[\mathrm{Di}^{\mathrm{R}}\right] 2 \& 3$ can be the reaction describing rodingite formation because $\left[\mathrm{Grt}^{\mathrm{R}}\right] 2 \& 3$ and $\left[\mathrm{Grt}^{\mathrm{R}}\right] 3 \& 1$ do not produce garnet and [Di] $3 \& 1$ describes the compositional change of chlorite with participation of minor amounts of other minerals. Thus we get the following reaction:

$$
\begin{aligned}
& \text { 1.00 } \mathrm{Di}+0.74 \mathrm{Chl}+1.56 \mathrm{Ep}+1.88 \mathrm{CaO}+0.18 \mathrm{H}_{2} \mathrm{O}= \\
& 2.00 \mathrm{Grt}^{\mathrm{R}}+0.86 \mathrm{Chl}^{\mathrm{R}}(\mathrm{R} 4, \text { Table } 4),
\end{aligned}
$$

where moles of open components, $\mathrm{CaO}$ and $\mathrm{H}_{2} \mathrm{O}$, are calculated using the data in Table 5. This reaction implies that rodingite formation can be explained by the addition of considerable amounts of $\mathrm{CaO}$ and $\mathrm{H}_{2} \mathrm{O}$ to the protolith (gabbro), whereas other components such as $\mathrm{SiO}_{2}, \mathrm{AF}$, and $\mathrm{FM}$ are preserved. The subsystem $\mathrm{CaO}-\mathrm{SiO}_{2}-\mathrm{FM}$ does not yield a proper reaction. The subsystems $\mathrm{CaO}-\mathrm{AF}-\mathrm{FM}$ and $\mathrm{CaO}-\mathrm{SiO}_{2}-\mathrm{AF}$ each yield only one proper reaction, which are given as follows: 
Table 5 Matrix for SVD analysis of rodingite-forming reactions and the results

\begin{tabular}{|c|c|c|c|c|c|c|}
\hline & \multicolumn{3}{|c|}{ Reactants (131019-MG) } & \multicolumn{3}{|c|}{ Products (131018-1B) } \\
\hline & $\overline{\mathrm{Di}}$ & $\mathrm{Chl}$ & Ep & $\overline{D i^{R a}}$ & $\mathrm{Grt}^{\mathrm{Ra}}$ & $\mathrm{Ch}^{\mathrm{Ra}}$ \\
\hline $\mathrm{Ca}$ & 0.93 & 0 & 2.03 & 0.96 & 2.98 & 0.02 \\
\hline Si & 1.95 & 5.82 & 3.02 & 1.98 & 3.01 & 5.76 \\
\hline $\mathrm{Al}+\mathrm{Fe}^{3+}$ & 0.09 & 4.66 & 2.95 & 0.05 & 1.99 & 4.84 \\
\hline $\mathrm{Mg}+\mathrm{Fe}^{2+}$ & 1.01 & 9.32 & 0 & 0.99 & 0 & 9.20 \\
\hline \multicolumn{7}{|c|}{ SiO2-AF-FM subsystem } \\
\hline & Di & Chl & Ep & $\mathrm{Di}^{\mathrm{R}}$ & $\mathrm{Grt}^{\mathrm{R}}$ & $\mathrm{Chl}^{\mathrm{R}}$ \\
\hline Reaction 1 & -0.669 & 0.158 & 0.107 & 0.689 & -0.125 & -0.161 \\
\hline Reaction 2 & -0.316 & 0.062 & -0.566 & -0.101 & 0.752 & -0.017 \\
\hline Reaction 3 & -0.127 & -0.685 & -0.049 & 0.204 & 0.010 & 0.686 \\
\hline \multicolumn{7}{|c|}{ Linear combination of reactions $2 \& 3$} \\
\hline$[\mathrm{Di}] 2 \& 3(\mathrm{R} 4)$ & -1.000 & -0.736 & -1.557 & 0.000 & 1.996 & 0.855 \\
\hline$\left[\mathrm{Grt}^{\mathrm{R}}\right] 2 \& 3$ & -1.000 & -5.590 & -0.344 & 1.670 & 0.000 & 5.592 \\
\hline \multicolumn{7}{|c|}{ Linear combination of reactions $3 \& 1$} \\
\hline [Di]3\&1 & 0.000 & -1.000 & -0.097 & 0.102 & 0.046 & 1.002 \\
\hline$\left[\mathrm{Grt}^{\mathrm{R}}\right] 3 \& 1$ & -1.000 & -3.789 & -0.232 & 1.441 & 0.000 & 3.793 \\
\hline \multicolumn{7}{|c|}{ CaO-AF-FM subsystem } \\
\hline & Di & $\mathrm{Chl}$ & Ep & $\mathrm{Di}^{\mathrm{R}}$ & $\mathrm{Grt}^{\mathrm{R}}$ & $\mathrm{Chl}^{\mathrm{R}}$ \\
\hline Reaction 5 & -1.000 & -2.677 & -1.051 & 0.000 & 1.009 & 2.822 \\
\hline \multicolumn{7}{|c|}{$\mathrm{CaO}-\mathrm{SiO}_{2}-\mathrm{AF}$ subsystem } \\
\hline & $\mathrm{Di}$ & $\mathrm{Chl}$ & Ep & $D i^{R}$ & $\mathrm{Grt}^{\mathrm{R}}$ & $\mathrm{Chl}^{\mathrm{R}}$ \\
\hline Reaction 6 & -1.000 & 0.000 & -1.530 & 0.131 & 1.309 & 0.411 \\
\hline
\end{tabular}

${ }^{\mathrm{a}} \mathrm{R}$ denotes minerals in rodingite

$1.00 \mathrm{Di}+2.68 \mathrm{Chl}+1.05 \mathrm{Ep}+0.64 \mathrm{H}_{2} \mathrm{O}=1.01 \mathrm{Grt}^{\mathrm{R}}+$ $2.82 \mathrm{Chl}^{\mathrm{R}}+1.41 \mathrm{SiO}_{2}(\mathrm{R} 5)$,

and

1.00 Di + 1.53 Ep + 2.91 FM + 2.53 $\mathrm{H}_{2} \mathrm{O}=0.13 \mathrm{Di}^{\mathrm{R}}+$

$1.31 \mathrm{Grt}^{\mathrm{R}}+0.41 \mathrm{Chl}(\mathrm{R} 6)$,

respectively. Large amounts of chlorites $\left(\mathrm{Chl}\right.$ and $\left.\mathrm{Chl}^{\mathrm{R}}\right)$ appear on both sides of the reaction (R5), whereas the mode of chlorite (7 vol.\%) in the metagabbro is small compared to that of diopside (65 vol.\%). The reaction (R6) produces both diopside and garnet, whereas in the rodingite, diopside is replaced by garnet (Fig. 2e). For these reasons, reactions (R5) and (R6) cannot be considered representative reactions in rodingite formation. Therefore, the reaction (R4) is the most appropriate reaction describing rodingite formation. This result supports the theory that the infiltration of Ca-rich fluids leads to the formation of rodingite (e.g., O'Brien and Rodgers 1973; Leach and Rodgers 1978; Wares and Martin 1980; Schandl et al. 1989; Python et al. 2011) rather than loss of $\mathrm{SiO}_{2}$ from the protolith and the resultant enrichment of
$\mathrm{CaO}$ in rodingite (e.g., Coleman, 1967). Serpentinization can produce Ca-rich fluid (e.g., Honnorez and Kirst 1975; Evans et al. 1979), and present-day serpentinization accompanies $\mathrm{Ca}^{2+}-\mathrm{OH}^{-}$-type waters (Barnes and O'Neill 1978), thus validating our conclusion.

\section{Extent of equilibrium in reaction zones}

This section describes the compositional variations of diopside and chlorite in the rodingite to serpentinite through reaction zones, showing disequilibrium crystallization of diopside in the reaction zones. Figure 5 shows the compositional variation of chlorite across the reaction zone from serpentinite to rodingite. The chlorite shows a monotonous compositional change, and $\mathrm{Mg}$ and $\mathrm{Si}$ decrease from serpentinite to rodingite with reverse trends of $\mathrm{Al}$ and $\mathrm{Fe}$. This change is due to the reaction between the rodingite (or its protolith) that is richer in $\mathrm{Al}_{2} \mathrm{O}_{3}$ and poorer in $\mathrm{MgO}$, and the serpentinite with a higher $\mathrm{Mg \#}(\mathrm{MgO} /$ $(\mathrm{MgO}+\mathrm{FeO})$ in weight percent). A decrease of $\mathrm{Si}$ in the chlorite from serpentinite to rodingite indicates Tschermak's substitution, rather than $\mathrm{SiO}_{2}$ transfer from serpentinite to rodingite. Figure 6 shows another compositional cross section indicating variations of $\mathrm{Ca}, \mathrm{Al}, \mathrm{Mg}$, and $\mathrm{Fe}$ in the diopside across the reaction zone. The diopside is homogeneous in serpentinite but becomes quite heterogeneous in the reaction zone, showing serrated variations in $\mathrm{Ca}, \mathrm{Al}$, and $\mathrm{Fe}$. In close proximity to the rodingite, diopside occurs as composite grains of Fe-rich and Fe-poor compositions as described in the "Method/Experimental" section. Because this feature is also observed in the rodingite, the region of composite diopside grains is named "twodiopside zone" as shown in Fig. 6. The two-diopside zone does not coincide with reaction zone 1 . Reaction zones 1 and 2 in this rock are defined by their modal compositions, whereas the two-diopside zone is defined by the occurrence of composite diopside grains. Figures $6 \mathrm{a}, \mathrm{b}$ show compositional variations of Fe-rich diopside and Fe-poor diopside, respectively. In the region outside the two-diopside zone, the data in Fig. $6 \mathrm{~b}$ are the same as those in Fig. 6a. Thus, diopside shows a disequilibrium relation not only across the reaction zone (serrated variation) but also within grains, where the composite gains consist of Fe-rich and -poor parts. These compositional heterogeneities, together with the occurrence of fine-grained diopside, clearly indicate that disequilibrium crystallization occurred in a relatively short-time period compared to that of the metamorphism. That is, the two diopsides crystallized simultaneously, reflecting the local bulk compositions. The reason why the chlorite is more homogeneous than diopside may be possible because diffusion in chlorite was significantly faster than that in diopside, due to its crystal structure. 


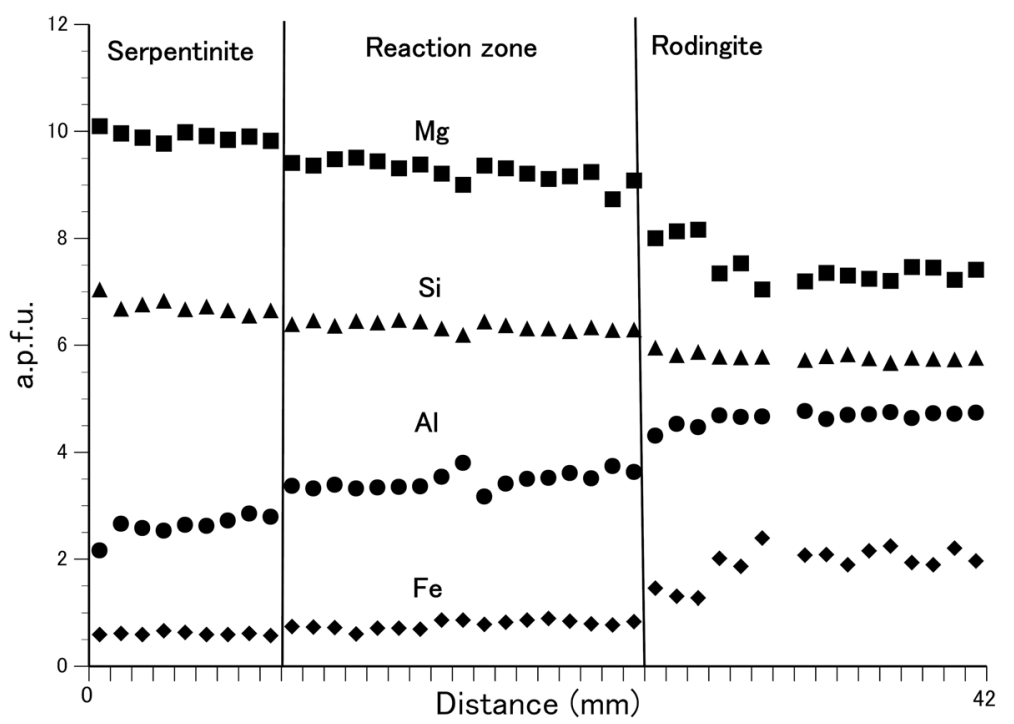

Fig. 5 Compositional cross section across the reaction zone between serpentinite and rodingite (131019-2). In this plot showing variations of Si, $\mathrm{Al}, \mathrm{Mg}$, and Fe (apfu) of chlorite, Mg and Si decrease monotonously from serpentinite to rodingite, whereas Al and Fe show reverse trends

\section{Significance of perovskite}

Perovskite $\left(\mathrm{CaTiO}_{3}\right)$ occurs in several reaction zones between serpentinite and rodingite as described in "Method/ Experimental" section (Table 1). Perovskite associated with rodingitization has also been reported in Slovakia by $\mathrm{Li}$ et al. (2014). They recognized two types of perovskite: one in rodingite and the other in the chlorite-rich blackwall zone (reaction zone). They used the $\mathrm{U} / \mathrm{Pb}$ secondary iron mass spectrometer (SIMS) to determine the concordia ages of 137-135 Ma for the former and 134 Ma for the latter type of perovskite. They concluded that such a negligible age difference implies that a relatively short-lived rodingitization event is responsible for the crystallization of both the perovskite generations. Perovskite is a relatively rare mineral because it is stable only in silica-deficient environments. If excess silica is present, perovskite will form titanite $\left(\mathrm{CaTiSiO}_{5}\right)$. As shown in Table 1, titanite occurs in some of the rodingites in the study area, whereas perovskite occurs only in the reaction zones. Perovskite occasionally shows a symplectic structure with diopside (Fig. 4c), indicating a pseudomorph after titanite. This relation clearly indicates that perovskite is formed by the breakdown of titanite in the silica-deficient environment of the reaction zone. This constraint is critical in subsequent discussions on reaction relations forming the reaction zone as derived by the SVD method.

\section{Interplay of irreversible reactions and hydrofracturing}

This subsection derives reaction relations that formed the reaction zone between the serpentinite and rodingite, to explain why and how the tremolite veins develop in serpentinites located close to the reaction zone (Fig. 4a). Taking the vein-type rodingite $131048-4 \mathrm{~A}$ as an example, the $\mathrm{CaO}-\mathrm{SiO}_{2}-\mathrm{AF}\left(\mathrm{Al}_{2} \mathrm{O}_{3}+\mathrm{Fe}_{2} \mathrm{O}_{3}\right)-\mathrm{FM}(\mathrm{FeO}+\mathrm{MgO})-$ $\mathrm{H}_{2} \mathrm{O}$ five-component system is considered. Antigorite from serpentinite, diopside, garnet, and chlorite from rodingite, and diopside ${ }^{\mathrm{RZ}}$ and chlorite ${ }^{\mathrm{RZ}}$ from the reaction zone are considered. Diopside is quite heterogeneous in composition, and the average composition of Fe-poor diopside is used because it is much more dominant than Fe-rich diopside. The heterogeneity in the diopside is mostly due to $\mathrm{Fe}^{2+}-\mathrm{Mg}$ exchange, and it does not affect our analysis because $\mathrm{Fe}^{2+}$ and $\mathrm{Mg}$ are treated as a single component (FM). The superscript $\mathrm{RZ}$ denotes minerals from the reaction zone because they have compositions different from those in the rodingite. Titanite, perovskite, and vesuvianite were not included in the analysis because they are present only in small amounts. We determined whether the reactions between serpentinite and rodingite that lead to the formation of the reaction zone evolve water or not under a constraint of constant solid volume before and after the reactions. The constant solid volume condition was incorporated because no deformation was observed in the reaction zone. If the reactions evolved water, it inevitably caused hydrofracturing (Nishiyama, 1989a) because serpentinite has low permeability. First, we attempted to find reaction relations that hold the conservation of pseudoquarternary components $\mathrm{CaO}-\mathrm{SiO}_{2}-$ $\mathrm{AF}\left(\mathrm{Al}_{2} \mathrm{O}_{3}+\mathrm{Fe}_{2} \mathrm{O}_{3}\right)-\mathrm{FM}(\mathrm{FeO}+\mathrm{MgO})$ among the mineral assemblage containing all minerals occurring in the serpentinite, rodingite, and the reaction zone. Because no reaction relation was found, we considered $\mathrm{CaO}$ to be a mobile component (i.e., a component that was not preserved before and after the reaction) and omitted it from the system. We then attempted to find reaction relations 

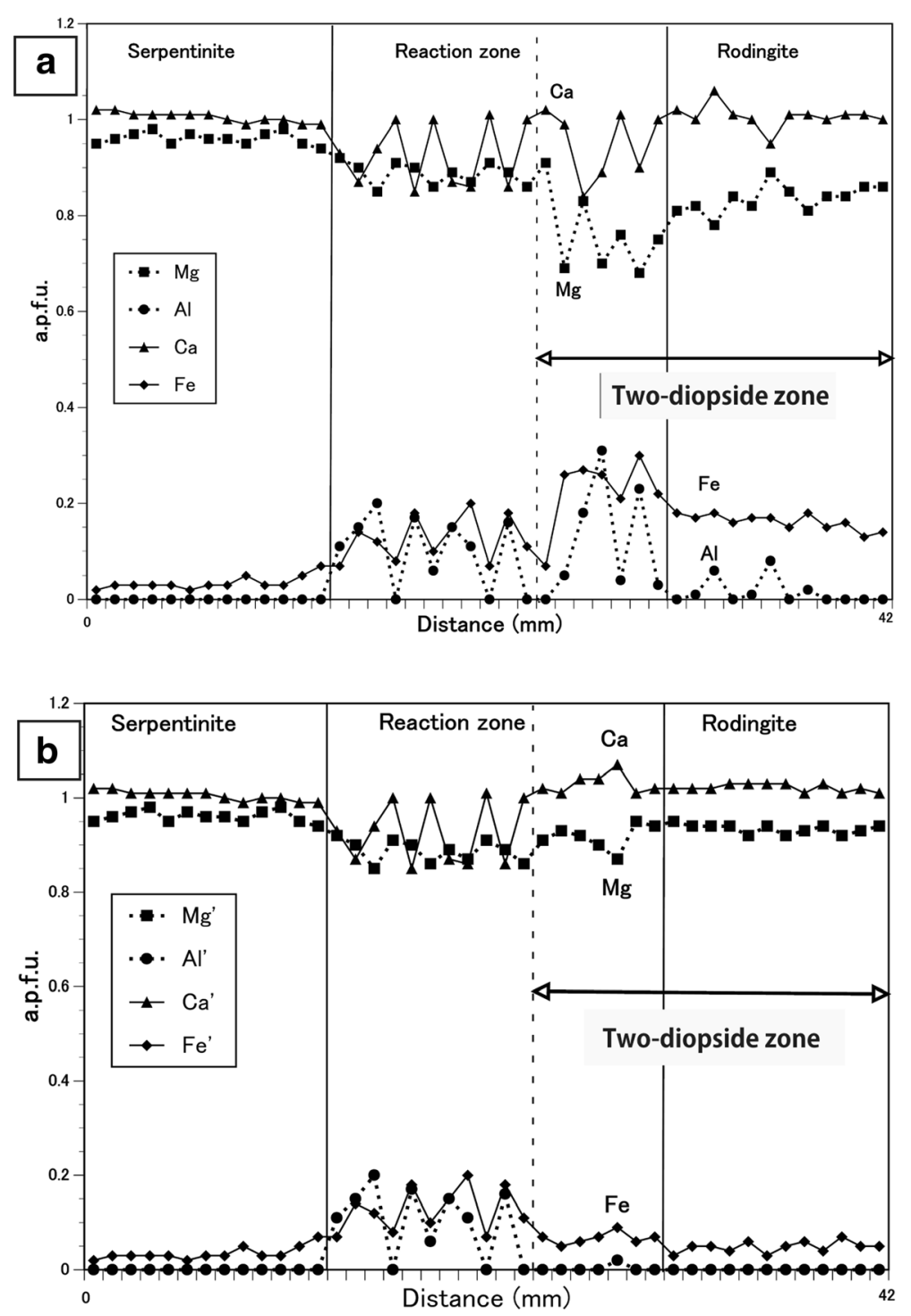

Fig. 6 Compositional cross section across the reaction zone between serpentinite and rodingite (131019-2). a Compositional variation of Fe-rich diopside in the "two-diopside zone". b Compositional variation of Fe-poor diopside in the "two-diopside zone"; data outside this zone are the same as those in $\mathbf{a}$. The diopside is homogeneous in the serpentinite, whereas it becomes quite heterogeneous both in the reaction zone and in the rodingite. Serrated variations in Ca and Al are notable in the reaction zone, and Fe-rich and -poor diopsides coexist in the rodingite and also in the reaction zone close to the rodingite (in the region entitled "two-diopside zone" in the figure)

that hold the conservation of pseudoternary components $\mathrm{SiO}_{2}-\mathrm{AF}-\mathrm{FM}$ for the same mineral assemblage. Table 6 shows the results for the $\mathrm{SiO}_{2}-\mathrm{AF}-\mathrm{FM}$ system. It should be noted that a row consisting of molar volumes of corresponding minerals was added to the composition matrix for SVD analysis to ensure the constant solid volume condition, as per the method in Yuguchi et al. (2015). The molar volume data were taken from Helgeson et al. (1978), considering the chlorite as clinochlore and the garnet as grossular. Two reactions, reaction 7 and reaction 8 in Table 6, were found in the system $\mathrm{SiO}_{2}-\mathrm{AF}-\mathrm{FM}$. Only reaction 7 satisfied the sign convention relation, which is negative for reactants and positive for products. Reaction 7 can be rewritten so as to normalize the stoichiometric coefficient of antigorite as unity as follows:

$1 \mathrm{Atg}+10.23 \mathrm{Di}+3.14 \mathrm{Grt}+0.66 \mathrm{Chl}+4.39 \mathrm{CaO}=$ $51.80 \mathrm{Di}^{\mathrm{RZ}}+4.01 \mathrm{Chl}^{\mathrm{RZ}}+4.26 \mathrm{H}_{2} \mathrm{O}$. (R7)

Two more reactions were obtained from the linear combinations of reaction 7 and reaction 8 : 
Table 6 Matrix for SVD analysis of 131018-4A and the results

\begin{tabular}{|c|c|c|c|c|c|c|}
\hline & \multicolumn{4}{|c|}{ Reactants } & \multicolumn{2}{|c|}{ Products } \\
\hline & Atg & Di & Grt & $\mathrm{Chl}$ & $D i^{R Z}$ & $\mathrm{Chl}^{\mathrm{RZ}}$ \\
\hline Si & 32.397 & 2.01 & 2.96 & 5.74 & 1.95 & 6.36 \\
\hline $\mathrm{AF}$ & 4.433 & 0 & 2.09 & 4.83 & 0 & 3.55 \\
\hline FM & 44.37 & 0.98 & 0 & 9.27 & 0.97 & 9.95 \\
\hline$V^{a}$ & 41.805 & 1.5796 & 2.9947 & 9.9 & 1.5796 & 9.9 \\
\hline
\end{tabular}

Results in Si-AF-FM system

\begin{tabular}{|c|c|c|c|c|c|c|}
\hline Reaction 7 & -0.015 & -0.612 & -0.048 & -0.010 & 0.787 & 0.061 \\
\hline Reaction 8 & -0.032 & -0.197 & 0.191 & -0.590 & -0.206 & \\
\hline \multicolumn{7}{|c|}{ Linear combination of reactions $7 \& 8$} \\
\hline [Grt](R9) & -1.000 & -28.590 & 0.000 & -6.830 & 31.840 & \\
\hline$[\mathrm{Chl}](\mathrm{R} 10)$ & -1.000 & -41.480 & -3.480 & 0.000 & 53.950 & \\
\hline \multicolumn{7}{|c|}{ Results in AF-FM subsystem } \\
\hline Reaction 11 & -0.022 & 0.792 & -0.276 & 0.405 & 0.037 & \\
\hline eaction 12 & -0.054 & -0.144 & -0.231 & 0.097 & 0.953 & \\
\hline Reaction 13 & -0.089 & 0.515 & -0.087 & -0.421 & 0.040 & \\
\hline \multicolumn{7}{|c|}{ Linear combination of reactions $11 \& 12$} \\
\hline [Grt](R14) & -1.000 & -22.714 & 0.000 & -6.790 & 23.013 & \\
\hline$[\mathrm{Chl}](\mathrm{R} 15)$ & -1.000 & -6.882 & -3.386 & 0.000 & 19.460 & \\
\hline \multicolumn{7}{|c|}{ Liner combination of reactions $12 \& 13$} \\
\hline $\mathrm{Di}(\mathrm{R} 16)$ & -1.000 & 0.000 & -3.235 & -0.264 & 12.245 & \\
\hline [Chl](R17) & -1.000 & -0.342 & -3.369 & 0.000 & 12.945 & \\
\hline
\end{tabular}

${ }^{\mathrm{a}} \mathrm{V}$ denotes molar volume (cal/bar) from Helgeson et al.(1978)

$1 \mathrm{Atg}+28.59 \mathrm{Di}+6.83 \mathrm{Chl}+4.24 \mathrm{CaO}=31.84 \mathrm{Di}^{\mathrm{RZ}}+$ $10.55 \mathrm{Ch}^{\mathrm{RZ}}+1.27 \mathrm{H}_{2} \mathrm{O}$ [Grt] (R9) and

$1 \mathrm{Atg}+41.49 \mathrm{Di}+3.48 \mathrm{Grt}+4.40 \mathrm{CaO}=53.95 \mathrm{Di}^{\mathrm{RZ}}+$ $3.30 \mathrm{Ch}^{\mathrm{RZ}}+4.59 \mathrm{H}_{2} \mathrm{O}[\mathrm{Chl}](\mathrm{R} 10)$.

All three reactions consume $\mathrm{CaO}$ and evolve $\mathrm{H}_{2} \mathrm{O}$, strongly suggesting an association between the increment of fluid pressure with the progress of the reactions. We have further examined the AF-FM system (Table 6) to get the following reactions:

$$
\begin{aligned}
& \text { 1Atg + 22.71Di }+6.79 \mathrm{Chl}+4.11 \mathrm{CaO}+0.40 \mathrm{SiO}_{2}= \\
& 26.01 \mathrm{Di}^{\mathrm{RZ}}+10.49 \mathrm{Chl}^{\mathrm{RZ}}+1.43 \mathrm{H}_{2} \mathrm{O}[\mathrm{Grt}](\mathrm{R} 14) ; \\
& 1 \mathrm{Atg}+6.88 \mathrm{Di}+3.39 \mathrm{Grt}+3.74 \mathrm{CaO}+3.32 \mathrm{SiO}_{2}= \\
& 19.46 \mathrm{Di}{ }^{\mathrm{RZ}}+3.24 \mathrm{Chl}^{\mathrm{RZ}}+5.06 \mathrm{H}_{2} \mathrm{O}[\mathrm{Chl}](\mathrm{R} 15) ; \\
& 1 \mathrm{Atg}+3.24 \mathrm{Grt}+0.26 \mathrm{Chl}+3.61 \mathrm{CaO}+2.74 \mathrm{SiO}_{2}= \\
& 12.25 \mathrm{Di}^{\mathrm{RZ}}+3.51 \mathrm{Ch}^{\mathrm{RZ}}+5.01 \mathrm{H}_{2} \mathrm{O}[\mathrm{Di}](\mathrm{R} 16) ; \text { and } \\
& 1 \mathrm{Atg}+0.34 \mathrm{Di}+3.37 \mathrm{Grt}+3.62 \mathrm{CaO}+2.75 \mathrm{SiO}_{2}= \\
& 12.95 \mathrm{Di}^{\mathrm{RZ}}+3.23 \mathrm{Chl}^{\mathrm{RZ}}+5.14 \mathrm{H}_{2} \mathrm{O}[\mathrm{Chl}](\mathrm{R} 17) .
\end{aligned}
$$

All of these reactions consume $\mathrm{SiO}_{2}$ and $\mathrm{CaO}$ and evolve $\mathrm{H}_{2} \mathrm{O}$. This relation holds if we take any linear combination of the above four reactions. When we consider the perovskite formation from titanite in the reaction zone, reactions in the AF-FM system are preferable because $\mathrm{SiO}_{2}$ liberated by the titanite breakdown will be consumed by the above reactions in the AF-FM system. To conclude, we have successfully derived reaction relations in the rodingite-serpentinite system under constant solid volume conditions. All reactions evolve $\mathrm{H}_{2} \mathrm{O}$, which strongly suggests that hydrofracturing is associated with these reactions. The results are consistent with the field observation that the tremolite veins are derived from the reaction zone into the serpentinite (Fig. 4a).

The above discussions are based on the assumption of conservation of solid volume during the formation of the reaction zone, which will be a strong constraint for deriving the reaction relations. Apart from vein formation, there is no evidence of deformation due to strain accumulation around the reaction zones in the outcrops. This observation may not be strong enough to support the assumption; therefore, we examined the reactions without the volume constraint for comparison. Table 7 summarizes the results, with values of $\Delta \mathrm{V}$ representing the relative change in solid volume due to the reaction. The four-component $\mathrm{CaO}-\mathrm{SiO}_{2}-\mathrm{AF}-\mathrm{FM}$ system does not yield proper reaction relations. We examined the reactions in the four subsystems: $\mathrm{CaO}-\mathrm{SiO}_{2}-\mathrm{AF}, \mathrm{CaO}-\mathrm{SiO}_{2}-\mathrm{FM}$, $\mathrm{CaO}-\mathrm{AF}-\mathrm{FM}$, and $\mathrm{SiO}_{2}-\mathrm{AF}-\mathrm{FM}$. We found two possible reactions in each subsystem, all of which are dehydration reactions. The two reactions in the $\mathrm{CaO}-\mathrm{SiO}_{2}-\mathrm{AF}$ subsys-

\begin{tabular}{|c|c|}
\hline $\mathrm{CaO}-\mathrm{SiO}_{2}-\mathrm{AF}$ subsystem & $\Delta \mathrm{V}$ \\
\hline $\begin{array}{l}1.00 \mathrm{Atg}+12.98 \mathrm{Di}+4.28 \mathrm{Grt}+3.92 \mathrm{FM}=24.21 \mathrm{Di}^{\mathrm{RZ}}+ \\
3.77 \mathrm{Chl}^{\mathrm{RZ}}+0.83 \mathrm{H}_{2} \mathrm{O}\end{array}$ & $0.60 \%$ \\
\hline $\begin{array}{l}1.00 \mathrm{Atg}+3.84 \mathrm{Di}+4.11 \mathrm{Grt}+2.77 \mathrm{FM}=14.86 \mathrm{Di}^{\mathrm{RZ}}+ \\
3.67 \mathrm{Chl}^{\mathrm{RZ}}+1.67 \mathrm{H}_{2} \mathrm{O}\end{array}$ & $-0.60 \%$ \\
\hline \multicolumn{2}{|l|}{$\mathrm{CaO}-\mathrm{SiO}_{2}-\mathrm{FM}$ subsystem } \\
\hline $\begin{array}{l}\text { 1.00Atg }+12.67 \mathrm{Di}+8.06 \mathrm{Grt}=34.16 \mathrm{Di}^{\mathrm{RZ}}+2.39 \mathrm{Chl}^{\mathrm{RZ}}+ \\
61.38 \mathrm{AF}+11.90 \mathrm{H}_{2} \mathrm{O}\end{array}$ & $-70.80 \%$ \\
\hline $\begin{array}{l}1.00 \mathrm{Atg}+7.14 \mathrm{Di}+7.27 \mathrm{Grt}=26.65 \mathrm{Di}^{\mathrm{RZ}}+2.57 \mathrm{Ch}^{\mathrm{RZ}}+ \\
45.34 \mathrm{AF}+10.41 \mathrm{H}_{2} \mathrm{O}\end{array}$ & $-61.69 \%$ \\
\hline \multicolumn{2}{|l|}{ CaO-AF-FM subsystem } \\
\hline $\begin{array}{l}\text { 1.00Atg }+9.47 \mathrm{Di}+3.81 \mathrm{Grt}=19.53 \mathrm{Di}^{\mathrm{RZ}}+3.49 \mathrm{Ch}^{\mathrm{RZ}}+ \\
2.43 \mathrm{SiO}_{2}+3.07 \mathrm{H}_{2} \mathrm{O}\end{array}$ & $-4.10 \%$ \\
\hline $\begin{array}{l}\text { 1.00Atg }+1.80 \mathrm{Di}+3.77 \mathrm{Grt}=11.98 \mathrm{Di}^{\mathrm{RZ}}+3.47 \mathrm{Chl}^{\mathrm{RZ}}+ \\
\text { 1.75 } \mathrm{SiO}_{2}+3.24 \mathrm{H}_{2} \mathrm{O}\end{array}$ & $-4.80 \%$ \\
\hline \multicolumn{2}{|l|}{$\mathrm{SiO}_{2}-\mathrm{AF}-\mathrm{FM}$ subsystem } \\
\hline $\begin{array}{l}1.00 \mathrm{Atg}+7.11 \mathrm{Di}+3.59 \mathrm{Grt}+1.85 \mathrm{CaO}=18.43 \mathrm{Di}^{\mathrm{RZ}}+ \\
3.36 \mathrm{Chl}^{\mathrm{RZ}}+4.08 \mathrm{H}_{2} \mathrm{O}\end{array}$ & $-2.20 \%$ \\
\hline $\begin{array}{l}\text { 1.00Atg + 0.34 Di }+3.62 \mathrm{Grt}+1.35 \mathrm{CaO}=11.44 \mathrm{Di}^{\mathrm{RZ}}+ \\
3.38 \mathrm{Ch} \mathrm{l}^{\mathrm{RZ}}+3.97 \mathrm{H}_{2} \mathrm{O}\end{array}$ & $-3.10 \%$ \\
\hline
\end{tabular}
tem consume large amounts of the FM component, whereas the two reactions in the $\mathrm{CaO}-\mathrm{SiO}_{2}-\mathrm{FM}$ subsystem evolve large amounts of the $\mathrm{AF}$ component. If this actually occurred, some chlorite veins would have been present around the reaction zones; however, these were none. Thus, there is little evidence to support the theory

Table 7 Reaction relations without volume constraints 
of the mass transfer of these components. In the $\mathrm{CaO}-\mathrm{AF}-\mathrm{FM}$ subsystem, $\mathrm{SiO}_{2}$ is liberated, which is contrary to the occurrence of perovskite in the reaction zone. As a result, no reaction without volume constraint is consistent with our observation of the reaction zone. These considerations strongly support the validity of our treatment of the solid volume conservation.

\section{Condition for hydrofracturing}

Hydrofracturing requires the accumulated fluid pressure to be higher than the lithostatic pressure. The condition for hydrofracturing can be written as

$$
P_{\text {fluid }}>\sigma_{3}+T_{0}
$$

where $\sigma_{3}$ denotes the minimum principal stress, and $T_{0}$ is the tensile strength of the rock. Such an accumulation of fluid pressure can be possible if the following two conditions are fulfilled (Nishiyama, 1989a): (1) fluid production rate is significantly faster than the fluid advection rate and (2) the rock deformation rate is small enough to prevent the relaxation of fluid pressure. These conditions are more likely to be satisfied by contact metamorphism rather than regional metamorphism because the reaction rate is significantly faster in contact metamorphism because heat transfer is more rapid than that it is in regional metamorphism. The rock deformation is also limited in contact metamorphism. However, our case study showed highly irreversible conditions for the formation of the reaction zone, implying rapid reaction rates. In such a case, if the country rocks (serpentinite in our case) are impermeable, the fluid pressure can be accumulated until the conditions required for hydrofracturing are met. The serpentinite in the study area is massive and not porous, implying very low permeability. These conditions made it possible for hydrofracturing to occur in the serpentinite located close to the reaction zone.

\section{Tremolite vein formation}

Tremolite vein formation can be explained by considering real chemical species in metamorphic fluid rather than oxide components used above for mass balance calculations. The hydrolysis reaction of a mineral can be expressed in a general form (Helgeson, 1968) as

$$
\mathrm{MO}_{\mathrm{z} / 2}+\mathrm{zH}^{+}=\mathrm{M}^{\mathrm{z}+}+(\mathrm{z} / 2) \mathrm{H}_{2} \mathrm{O}
$$

where $M$ represents a cation with positive valency z. For example, the hydrolysis reaction of diopside can be written as

$$
\mathrm{CaMgSi}_{2} \mathrm{O}_{6}+12 \mathrm{H}^{+}=\mathrm{Ca}^{2+}+\mathrm{Mg}^{2+}+2 \mathrm{Si}^{4+}+6 \mathrm{H}_{2} \mathrm{O} .
$$

This reaction implies that diopside is in equilibrium with cations in the metamorphic fluid such as $\mathrm{H}^{+}, \mathrm{Ca}^{2+}$,
$\mathrm{Mg}^{2+}$, and $\mathrm{Si}^{4+}$. The equilibrium condition can be written as follows by assuming the activities of pure solid (diopside) and water are unity:

$$
\operatorname{dln}\left(\frac{\mathrm{a}_{\mathrm{Ca}^{2+}}}{\mathrm{a}_{\mathrm{H}^{+}}^{2}}\right)+\operatorname{dln}\left(\frac{\mathrm{a}_{\mathrm{Mg}^{2+}}}{\mathrm{a}_{\mathrm{H}^{+}}^{2}}\right)+2 \mathrm{dln}\left(\frac{\mathrm{a}_{\mathrm{Si}^{4+}}}{\mathrm{a}_{\mathrm{H}^{+}}^{4}}\right)=0 .
$$

Similarly, we get the following equilibrium conditions for antigorite and tremolite:

$$
48 d \ln \left(\frac{\mathrm{a}_{\mathrm{Mg}^{2+}}}{\mathrm{a}_{\mathrm{H}^{+}}^{2}}\right)+34 \mathrm{dln}\left(\frac{\mathrm{a}_{\mathrm{Si}^{4+}}}{\mathrm{a}_{\mathrm{H}^{+}}^{4}}\right)=0 .
$$

for antigorite and

$$
2 \operatorname{dln}\left(\frac{\mathrm{a}_{\mathrm{Ca}^{2+}}}{\mathrm{a}_{\mathrm{H}^{+}}^{2}}\right)+5 \mathrm{dln}\left(\frac{\mathrm{a}_{\mathrm{Mg}^{2+}}}{\mathrm{a}_{\mathrm{H}^{+}}^{2}}\right)+8 \mathrm{dln}\left(\frac{\mathrm{a}_{\mathrm{S}^{4+}}}{\mathrm{a}_{\mathrm{H}^{+}}^{4}}\right)=0
$$

for tremolite, respectively. Figure 7 shows a schematic relation of these equilibrium conditions in a $\operatorname{In}\left(\frac{\mathrm{a}_{\mathrm{Ca}^{+}}}{\mathrm{a}_{\mathrm{H}^{+}}^{2}}\right) \mathrm{vs}$. $\operatorname{In}\left(\frac{\mathrm{a}_{\mathrm{Mg}^{2+}}}{\mathrm{a}_{\mathrm{H}^{+}}^{2}}\right)$ diagram under a fixed value of $\operatorname{In}\left(\frac{\mathrm{a}_{\mathrm{Si}^{4+}}}{\mathrm{a}_{\mathrm{H}^{+}}^{4}}\right)$. Because activities of $\mathrm{Mg}^{2+}$ and $\mathrm{Si}^{4+}$ are buffered by a large amount of antigorite, they can be considered to be constant during the formation of the reaction zone. Consider the initial condition as A in Fig. 7, in which both antigorite and

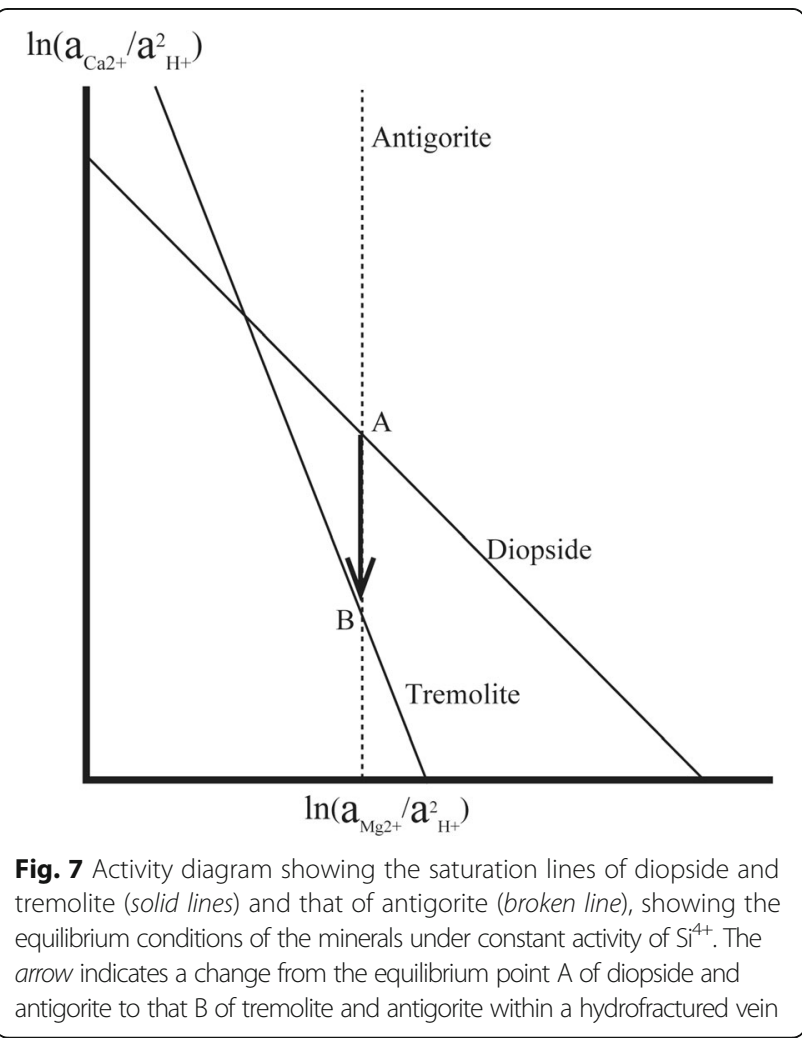


diopside are in equilibrium with the fluid in the serpentinite. Once a fracture is formed in the serpentinite by hydrofracturing, the activity of $\mathrm{Ca}^{2+}$ in the fluid filling the fracture will decrease owing to the addition of water evolved from the reaction forming the reaction zone. Then, the fluid composition will shift down from the point A to the new equilibrium point B shown in Fig. 7, resulting in the formation of tremolite. This is possible because the activity of $\mathrm{Ca}^{2+}$ will not be buffered by diopside owing to its small amount in serpentinite.

\section{Tectonic setting of rodingite formation}

Rodingites have been reported in ophiolites from various tectonic settings, mostly from the seafloor and rarely from the subduction zones (Koutsovitis et al. 2013). Honnorez and Kirst (1975) reported rodingites from the mid-Atlantic fracture zones together with serpentinized ultramafics and fresh and metamorphosed basalts and gabbros. They discussed that serpentinization took place in the deeper part of the oceanic crust and that rodingitization occurred simultaneously with the host serpentinization. Such rodingites from the ocean floor or from the oceanic lithosphere have also been reported by Frost et al. (2008), Austrheim and Prestvick (2008), and Bach and Klein (2009). Subduction-related rodingites have been reported in East Othris, Greece, by Koutsovitis et al. (2013) and in the Western Carpathians, Slovakia by $\mathrm{Li}$ et al. (2014). Koutsovitis et al. (2013)) discussed that the rodingitization took place in an intra-oceanic subduction system in three successive stages during the exhumation of the mafic-ultramafic mantle wedge rocks in a fore-arc setting within a serpentinite subduction channel. Li et al. (2014) found perovskite-bearing rodingites in a mélange type blueschist-bearing accretionary wedge complex. In our study area, Fukuyama et al. (2014) carried out geochemical studies on the rodingite. They found two types of zircons, prismatic, and porous types, from dyke-type rodingites. This indicates that Hafnium isotopic compositions of prismatic zircons are close to or identical to the $\mathrm{Hf}$ isotope ratio of the mid-ocean ridge basalt (MORB). They also showed that the high field strength element (HFSE) concentrations in the rodingites are similar to those of MORBs. They further determined that the low $\varepsilon_{\mathrm{Hf}}$ values $(11.8-18.9)$ of porous zircons indicate the incorporation of a small amount of $\mathrm{Hf}$ from fluid contaminated by subducted sediments. These lines of evidence clearly show that the protoliths of the rodingites in the Nomo metamorphic rocks are MORB-like basic rocks, suggesting the tectonic setting of the oceanic lithosphere. The rodingitization may have occurred in the oceanic lithosphere simultaneously with serpentinization and may have continued to the stage of the subduction as indicated by the occurrence of high-pressure minerals such as omphacite and alkali amphiboles from the serpentinite mélanges. Because antigorite is rare in oceanic serpentinites (Bach and Klein 2009), the abundant occurrence of antigorite in the Nomo serpentinite supports the continuing rodingitization in the subduction setting. The synchronous rodingitization with serpentinization is attributed to the hydrolysis reaction of diopside in serpentinite:

$$
\mathrm{CaMgSi}_{2} \mathrm{O}_{6}+12 \mathrm{H}^{+}=\mathrm{Ca}^{2+}+\mathrm{Mg}^{2+}+2 \mathrm{Si}^{4+}+6 \mathrm{H}_{2} \mathrm{O}
$$

This reaction will evolve the $\mathrm{Ca}^{2+}$ necessary for rodingitization of the basic rocks in the serpentinite. It should be noted that the above reaction also evolves $\mathrm{Si}^{4+}$, but the activity of $\mathrm{Si}^{4+}$ will be buffered by the hydrolysis reaction of antigorite. Therefore, the silica-deficient environments for rodingitization will not contradict with the above reaction.

\section{Conclusions}

The singular value decomposition (SVD) method is a powerful tool by which reaction relations among minerals with complex compositions can be systematically derived and the amount of mobile (open) components evaluated. Incorporation of molar volume data into the SVD matrix can assure the constant solid volume condition. The resulting reactions evolve $\mathrm{H}_{2} \mathrm{O}$, which strongly suggests that it is the cause for hydrofracturing leading to the formation of tremolite veins in the serpentinite. Heterogeneities in mineral compositions in the reaction zone imply that rapid irreversible reactions occurred during the formation of the reaction zone. This rapid progress of reactions is a necessary condition for hydrofracturing to occur. If the reaction proceeds slowly, the liberated water will escape from the reaction zone into serpentinite by porous flow, resulting in the relaxation of excess fluid pressure. Thus, tremolite vein associated with the reaction zone between the serpentinite and rodingite is a good example of the interplay between irreversible reactions and hydrofracturing. Our analysis clearly indicates that hydrofracturing can occur even in regional metamorphism if the reactions liberating $\mathrm{H}_{2} \mathrm{O}$ occur irreversibly.

\section{Abbreviations}

apfu: Atoms per formula unit; SVD: Singular value decomposition

\section{Acknowledgements}

The authors appreciate two anonymous reviewers for their constructive reviews and the editor T. Hirajima for his valuable suggestions and editorial handling. We thank D. Shiosaki for his help in our fieldwork and also in the EDS analysis. Discussions with the members of "Henseigan-nado (Metamorphic rocks etc.) Symposium" are acknowledged. Co-works in the SVD analysis with T. Yuguchi are appreciated.

\section{Funding}

This work was financially supported by JSPS KAKENHI Grant Number JP16H02238 to TN. 


\section{Authors' contributions}

TN designed the study. All authors carried out fieldworks together. Petrography and mineral chemistry were chiefly done by CY-S and TN with supports by YM and MS. The SVD analysis was conducted by TN. All authors read and approved the final manuscript.

\section{Competing interests}

The authors declare that they have no competing interests.

\section{Author details}

'Department of Earth and Environmental Science, Graduate School of Science and Technology, Kumamoto University, 2-39-1, Kurokami, Chuo-ku, Kumamoto 860-8555, Japan. ${ }^{2}$ Kitakyushu Museum of Natural History and Human History, 2-4-1, Higashida, Yahatahigashi-ku, Kitakyushu 805-0071, Japan.

Received: 28 June 2016 Accepted: 14 December 2016

\section{Published online: 16 January 2017}

\section{References}

Austrheim H, Prestvik T (2008) Rodingitization and hydration of the oceanic lithosphere as developed in the Leka ophiolite, north-central Norway. Lithos 104:177-198

Bach W, Klein F (2009) The petrology of seafloor rodingites: insights from geochemical reaction path modeling. Lithos 112:103-117

Barnes I, O'Neill JR (1978) Present day serpentinization in New Caledonia, Oman and Yugoslavia. Geochim Cosmochim Acta 42:144-145

Barriga F, Fyfe WS (1983) Development of rodingite in basaltic rocks in serpentinites, East Liguria, Italy. Contrib Mineral Petrol 84:146-151

Coleman RG (1967) Low-temperature reaction zones and alpine ultramafic rocks of California, Oregon, and Washington. US Geol Surv Bull 1247:1-49

El-Shazly AK, Al-Belushi M (2004) Petrology and chemistry of metasomatic blocks from Bawshir, northeastern Oman. Int Geol Rev 46:904-938

Evans BW, Trommsdorff V, Richter W (1979) Petrology of an eclogitemetarodingite suite at Cima di Ganone, Ticino, Switzerland. Amer Mineral 64:15-31

Fisher GW (1989) Matrix analysis of metamorphic mineral assemblages and reactions. Contrib Mineral Petrol 102:69-77

Frost BR, Beard JS, McCraig A, Condliffe E (2008) The formation of microrodingites from IODP hole U1309D: key to understanding the process of serpentinization. J Petrol 49:1579-1588

Fukuyama M, Ogasawara M, Dunkley D, Wang K-L, Lee D-C, Hokada T, Maki K, Hirata T, Kon Y (2014) The formation of rodingite in the Nagasaki metamorphic rocks at Nomo Peninsula, Kyushu, Japan-Zircon U-Pb and Hf isotopes and trace element evidence. Island Arc 23:281-293

Grant JA (2005) Isocon anlysis : a brief review of the method and applications. Phys Chem Earth 30:997-1004

Hattori J, Isomi H (1976) Geology of western part of Amakusa-Shimoshima and metamorphic rocks in northwest Kyushu. Monthly Rept Geol Surv Japan 27: 665-682 (in Japanese with English abstract)

Hattori J, Shibata K (1982) Radiometric dating of pre-Neogene granitic and metamorphic rocks in northwest Kyushu, Japan-with emphasis on geotectonics of the Nishisonogi zone. Bull Geol Surv Japan 33:57-84

Hatzipanagiotou K, Tsikouras B (2001) Rodingite formation from diorite in the Samothraki ophiolite, NE Aegean, Greece. Geol J 36:93-109

Helgeson HC (1968) Evaluation of irreversible reactions in geochemical processes involving minerals and aqueous solutions. Geochim Cosmochim Acta 32: 853-877

Helgeson HC, Delany JM, Nesbitt HW, Bird DK (1978) Summary and critique of the thermodynamic properties of rock-forming minerals. Amer J Sci 278-A:1-229

Honnorez J, Kirst P (1975) Petrology of rodingites from the equatorial midAtlantic fracture zones and their geotectonic significance. Contrib Mineral Petrol 49:233-257

Igi S, Hattori J, Shibata K (1979) Nomo metagbbro complex and their 450 m.y. ages as a clue to the basement geology. In: Editorial committee of The Professor Hiroshi Kano Memorial Volume' (ed). The Basement of the Japanese Islands, Akita University, Akita, pp 261-280, in Japanese with English abstract

Karakida Y (1980) An amphibolite - rodingite xenolith from Tsubokinohana, Kumamoto Prefecture. Sci Rep Dept Geol Kyushu Univ 13:85-97 (in Japanese with English abstract)
Kobayashi S, Kaneda H (2010) Rodingite with Ti- and $\mathrm{Cr}$ - rich vesuvianite from the Sartuohai chromium deposit, Xinjiang, China. J Mineral Petrol Sci 105:112-122 Koutsovitis P, Magganas A, Pomonis P, Ntaflos T (2013) Subduction-related rodingites from East Othris, Greece: mineral reactions and physicochemical conditions of formation. Lithos 172-173:139-157

Lang HM, Wachter AJ, Peterson VL, Ryan JQ (2004) Coexisting clinopyroxene/ spinel and amphibole/spinel symplectites in metatroctolites from the Buck Creek ultramafic body, North Carolina Blue Ridge. Amer Mineral 89:20-30

Leach TM, Rodgers KA (1978) Metasomatism in the Wairere serpentinite, King Country, New Zealand. Mineral Mag 42:45-62

Li X-H, Putiš M, Yang Y-H, Koppa M, Dyda M (2014) Accretionary wedge hartzburgite serpentinization and rodingitization constrained by perovskite $\mathrm{U} / \mathrm{Pb} \mathrm{SIMS}$ age, trace elements and $\mathrm{Sm} / \mathrm{Nd}$ isotopes: case study from the Western Carpathians, Slovakia. Lithos 205:1-14

Miyazaki K, Nishiyama T (1989) Petrological Study of the Nagasaki metamorphic rocks in the Nomo Peninsula - with special reference to biotite zone. Mem Geol Soc Japan 33:217-236 (in Japanese with English abstract)

Miyazaki K, Ikeda T, Arima K, Fukuyama M, Maki K, Yui T-F, Grove M (2013) Pressure-temperature structure of a mylonitized metamorphic pile, and the role of advection of the lower crust, Nagasaki Metamorphic Complex, Kyushu, Japan. Lithos 162-163:14-26

Muraoka H (1985) Serpentinization reaction responsible for rodingite formation of the Ashidachi ultramafic complex, Southwest Japan. J Japan Assoc Min Petr Econ Geol 80:413-428

Nishimura Y (1998) Geotectonic subdivision and areal extent of the Sangun belt, Inner Zone of Southwest Japan. J Metamorphic Geol 16:129-140

Nishimura Y, Hirota Y, Shiosaki D, Nakahara N (2004) The Nagasaki metamorphic rocks and their geotectonics in Mogi area, Nagasaki prefecture, Southwest Japan—juxtaposition of the Suo belt with the Sanbagawa belt. J Geol Soc Japan 110:372-383 (in Japanese with English abstract)

Nishiyama T (1989a) Kinetics of hydrofracturing and metamorphic veining. Geology 17:1068-1071

Nishiyama T (1989b) Petrological study of the Nagasaki metamorphic rocks in the Nishisonogi Peninsula - with special reference to the greenrock complex and the reaction enhanced ductility. Mem Geol Soc Japan 33:237-257 (in Japanese with English abstract)

Nishiyama T, Miyazaki K (1987) Omphacite-bearing reaction zone in the Nagasaki metamorphic rocks, the Nomo Peninsula. Sci Rept Dept Geol Kyushu Univ 15:89-101 (in Japanese with English abstract)

O'Brien JP, Rodgers KA (1973) Xonotlite and rodingites from Wairere, New Zealand. Mineral Mag 39:233-240

Python M, Yoshikawa M, Shibata T, Arai S (2011) Diopsidites and rodingtes: serpentinization and Ca-metasomatism in the Oman ophiolite mantle. In: Srivastava RK (ed) Dyke swarms: keys for geodynamic interpretation. Springer, Heidelberg, pp 401-435

Schandl ES, O'Hanley DS, Wicks FJ (1989) Rodingites in serpentinized ultramafic rocks of the Abitibi Greenstone belt, Ontario. Canad Mineral 27:579-591

Shigeno M, Mori Y, Shimada K, Nishiyama T (2012) Jadeitites with metasomatic zoning from the Nishisonogi metamorphic rocks, western Japan: fluidtectonic block interaction during exhumation. Eur J Mineral 24:289-311

Van Huffel S, Vanderwalle J (1991) The total least squares problem: computational aspects and analysis, Frontiers in Appliede Mathematics Series 9. SIAM, Philadelphia

Wares RP, Martin RF (1980) Rodingitization of granite and serpentinite in the Jeffre Mine, Asbestos, Quebec. Can Mineral 18:231-240

Whitney DL, Evans BW (2010) Abbreviations for names of rock-forming minerals. Amer Mineral 65:185-187

Yuguchi T, Sasao E, Ishibashi M, Nishiyama T (2015) Hydorthermal chloritization processes from biotite in the Toki granite, Central Japan: temporal variations of the compositions of hydrothermal fluids associated with chloritization. Amer Mineral 100:1134-1152 